Article

\title{
Effect of Cover Crop Type and Application Rate on Soil Nitrogen Mineralization and Availability in Organic Rice Production
}

\author{
Xiufen Li $^{1}{ }^{(\mathbb{D}}$, Andrew Tan ${ }^{2}$, Kun Chen ${ }^{3}$, Yeming Pan ${ }^{3}$, Terry Gentry ${ }^{4}\left(\mathbb{D}\right.$ and Fugen Dou ${ }^{1, *}$ \\ 1 Texas A\&M AgriLife Research Center at Beaumont, Texas A\&M University System, \\ Beaumont, TX 77713, USA; Xiufen.Li@wsu.edu \\ 2 School of Natural Sciences and Mathematics, University of Texas at Dallas, Richardson, TX 75080, USA; \\ adt190005@utdallas.edu \\ 3 Department of Statistics, University of Connecticut, Storrs, CT 06269, USA; kun.chen@uconn.edu (K.C.); \\ yeming.pan@uconn.edu (Y.P.) \\ 4 Department of Soil and Crop Sciences, Texas A\&M University, College Station, TX 77843, USA; \\ tjgentry@tamu.edu \\ * Correspondence: f-dou@aesrg.tamu.edu
}

Citation: Li, X.; Tan, A.; Chen, K.; Pan, Y.; Gentry, T.; Dou, F. Effect of Cover Crop Type and Application Rate on Soil Nitrogen Mineralization and Availability in Organic Rice Production. Sustainability 2021, 13, 2866. https://doi.org/10.3390/ su13052866

Academic Editor: Domenico Ronga

Received: 13 February 2021

Accepted: 2 March 2021

Published: 6 March 2021

Publisher's Note: MDPI stays neutral with regard to jurisdictional claims in published maps and institutional affiliations.

Copyright: (C) 2021 by the authors. Licensee MDPI, Basel, Switzerland. This article is an open access article distributed under the terms and conditions of the Creative Commons Attribution (CC BY) license (https:// creativecommons.org/licenses/by/ $4.0 /)$.

\begin{abstract}
In drill-seeded, delay-flooded organic rice production, reliable predictions of $\mathrm{N}$ supply from cover crop (CC) residues to subsequent rice are still a challenge. An incubation was conducted to determine the effects of CC types (clover, ryegrass, clover and ryegrass mixtures, and fallow), residue application rates $(0,0.6,1.2,1.8$, and $2.4 \%)$ and incubation time on soil $\mathrm{CO}_{2}$ evolution and $\mathrm{N}$ mineralization and availability. The cumulative $\mathrm{CO}_{2}$ evolution linearly increased with increasing residue rate. Compared to the control, adding CCs residue significantly increased the cumulative $\mathrm{CO}_{2}$ emission, which was greatest in soils with clover or mixtures of clover and ryegrass, followed by fallow, and lowest in soils with ryegrass. The modeling results indicated clover had the greatest initial $\mathrm{C}$ and $\mathrm{N}$ mineralization rates and the shortest half-lives. A temporary decrease in soil mineral $\mathrm{N}$ caused by immobilization occurred at the initial incubation stage in all treatments. However, the trend reversed progressively, with the clover treatment requiring the shortest time to meet the crossover point. The results suggested clover was the optimal CC type, $0.6 \%$ was the optimal residue rate, and a minimum of 27 days between CC termination and rice planting was required to maximize mineral $\mathrm{N}$ supply for organic rice.
\end{abstract}

Keywords: organic farming; cover crop; $\mathrm{N}$ mineralization; $\mathrm{N}$ supply; soil incubation; microbial decomposition

\section{Introduction}

The organic industry in the U.S. has expanded rapidly to keep pace with market demand, and the planting acreage of organic rice in the U.S. has increased from 20,757 to more than 79,000 acres since 1995 [1,2]. Improving nutrient management, especially nitrogen (N) management, is a crucial battlefront for improving organic production and has drawn rapidly increasing attention from researchers, decision-makers, and producers [3]. Cover crops, especially leguminous cover crops, have been proposed as an effective $\mathrm{N}$ source to increase soil fertility and crop productivity [4-6], minimize $\mathrm{N}$ losses through nitrate leaching [7-9], suppress weeds through releasing of allelopathic exudates or competing for light, water, and nutrients [10,11], and support other ecosystem services [12,13].

When cover crops are incorporated into soils, nitrogen in the tissues can be mineralized to provide mineral $\mathrm{N}$ to the following cash crops $[14,15]$. Despite being an ideal $\mathrm{N}$ strategy for organic farming, that currently relies heavily on natural soil amendments (e.g., manure) instead of cover crops, one big challenge in adopting the cover crop approach is accurately predicting when the nitrogen in cover crops will become available to the subsequent cash 
crops. Several studies reported that the incorporation of winter cover crops increased rice yield $5-10 \%$ [16-18]. However, some studies reported no statistically significant difference in rice grain yield between cover crop and non-cover crop treatments $[19,20]$. The varying results indicated the complexity of the cover crop decomposition and $\mathrm{N}$ release processes owing to multiple impact factors, including the types of cover crops [6,19], the C:N ratio and lignin content of the cover crops [13,21-24], the application rate of cover crops [25], the timing of cover crop incorporation [14,26], and soil and environmental conditions [27,28]. The varying results also underline the importance of selecting appropriate cover crop type, application rate, and termination time to maximize soil $\mathrm{N}$ availability for rice growth and present challenges to researchers.

To tackle the challenges, several studies focused on a modeling approach to capture changes in $\mathrm{N}$ availability from microbial decomposition after cover crop termination [25,29-31]. Based on the first-order kinetic models, clover needs 9-27 days and ryegrass needs 58 days to degrade $50 \%$ or more of the $\mathrm{N}$ mineralization potential $\left(\mathrm{N}_{0}\right)$ from cover crop residues [29,30,32]. Although considerable effort has been put into understanding the $\mathrm{N}$ dynamics after cover crop incorporation, $\mathrm{N}$ dynamics in organically managed soils, especially in drill-seeded, delay-flooded organic rice production, remain relatively unexplored, which prevents greater insight into the precise estimation of $\mathrm{N}$ mineralization and availability in organic rice. In organic rice field trials, winter cover crops are typically terminated from late March to early April and organic rice drill-seeded from late April to early May depending on the weather [33,34]. The focus of this study was to use an incubation trial to assess the dynamics of $\mathrm{N}$ mineralization after cover crop incorporation but before organic rice planting to predict soil available mineral $\mathrm{N}$ contents at planting and to improve soil $\mathrm{N}$ management in organic agriculture.

In microbial decomposition, the activities of microorganisms that decompose organic compounds into mineral forms are manageable through the adjustment of the C:N ratio [35], oxygen supply [36], moisture content [37], and temperature [37,38]. Laboratory incubations under controlled conditions hold constant environmental factors and have proved valuable in understanding $\mathrm{C}$ and $\mathrm{N}$ mineralization kinetics with inputs of diverse residue quality and quantity [39]. In this study, a 31-day aerobic incubation experiment was conducted using 1-L jars under controlled oxygen, moisture, and temperature conditions to determine the effects of cover crop type, residue application rate, and incubation time on soil $\mathrm{N}$ mineralization and mineral $\mathrm{N}$ availability. The observed data in the incubation experiment were also used to build $\mathrm{C}$ and $\mathrm{N}$ mineralization simulation models to estimate the $\mathrm{C}$ and $\mathrm{N}$ mineralization potentials $\left(\mathrm{C}_{0}\right.$ and $\left.\mathrm{N}_{0}\right)$ and half-lives $\left(t_{1 / 2}\right)$.

Specifically, the objectives were to (1) determine the effects of cover crop mixtures [control, white clover, annual ryegrass, $70 \%$ clover $+30 \%$ ryegrass (C7R3), 30\% clover + $70 \%$ ryegrass (C3R7), and fallow (volunteer weeds)], residue application rates $(0,0.6,1.2$, 1.8 , and $2.4 \%$ ), and incubation time on organically managed soil $\mathrm{CO}_{2}$ evolution, $\mathrm{C}$ and $\mathrm{N}$ mineralization potentials and half-lives, microbial biomass $\mathrm{C}$ and $\mathrm{N}$, organic $\mathrm{C}$ and $\mathrm{N}$ contents, and mineral $\mathrm{N}$ availability, and (2) estimate the optimal cover crop type, residue replication rate, and termination time to maximize $\mathrm{N}$ availability at planting for organic rice growth.

\section{Materials and Methods}

\subsection{Soil and Cover Crops Collection and Properties}

Cover crops used in this incubation experiment were collected from a certified organic rice field in 2014. The organic rice yields were 7443,7292 , and $7312 \mathrm{~kg} \mathrm{ha}^{-1}$ for the fields with clover (Trifolium repens), annual ryegrass (Lolium multiflorum), and fallow (volunteer weeds), respectively in 2012-2014 [33,34]. A total of $150 \mathrm{~kg}$ of surface soil $(0-15 \mathrm{~cm})$ was collected from a multiple-year fallow area of the certified organic field using a backhoe. Five cores of soil samples were mixed thoroughly, air-dried, ground, passed a 2-mm sieve, and stored in several large plastic cans for use in this study and other experiments in the organic project. The soil was a Morey loam (fine-silty, siliceous, superactive, hyperthermic 
Oxyaquic Argiudolls) with sand $47 \%$, silt $36 \%$, and clay $17 \%$, and other properties were shown in Table 1. Soil pH and EC were determined in a 1:2 (w/v) soil: deionized water extractant using a VWR Symphony B20PI Benchtop pH meter (VWR International, LLC., Radnor, PA, USA) and Mettler Toledo EC meter (Mettler-Toledo, LLC, Columbus, OH, USA) [40,41]. Soil total $\mathrm{C}$ and total $\mathrm{N}$ contents were determined using a total carbon analyzer by reducing the primary sample ignition furnace to $650{ }^{\circ} \mathrm{C}$ following a combustion procedure described by McGeehan and Naylor [42]. Soil P, K, Ca, Mg, Na, Zn, Fe, Cu, and $\mathrm{S}$ were extracted using the Mehlich III extractant and determined by inductively coupled plasma spectrophotometry (ICP) according to Mehlich [43,44].

Table 1. Properties of the background soil used for the laboratory incubation.

\begin{tabular}{|c|c|c|c|c|c|c|c|c|c|c|c|c|c|c|c|}
\hline & \multirow{2}{*}{$\mathrm{pH}$} & \multirow{2}{*}{$\begin{array}{c}\text { EC } \\
(\mu \mathrm{S} / \mathrm{cm})\end{array}$} & \multirow{2}{*}{$\begin{array}{c}\text { WHC } \\
(\%)\end{array}$} & Total C & Total N & DOC & DON & $\mathbf{N H}_{4}^{+}$ & $\mathrm{NO}_{2}^{-}$ & $\mathrm{NO}_{3}^{-}$ & $\mathbf{P}$ & $\mathrm{Ca}$ & $\mathrm{Mg}$ & $\mathrm{S}$ & $\mathrm{Na}$ \\
\hline & & & & \multicolumn{2}{|c|}{$\mathrm{g} \mathrm{kg}^{-1}$} & \multicolumn{10}{|c|}{$\mathrm{mg} \mathrm{kg}^{-1}$} \\
\hline Background Soil & 6.3 & 118 & 51.2 & 11.9 & 2.5 & 82.3 & 4.4 & 16.16 & 0.01 & 0.02 & 41 & 1891 & 211 & 18 & 55 \\
\hline
\end{tabular}

During our 2012-2014 organic rice field trials, the cover crops were planted from midOctober to early November, and terminated from late March to early April the following spring by cutting and tilling into soils with a John Deere disc (John Deere Pavilion, Moline, IL, USA) and a Lelyterra rotary harrow (Lely North America Inc., Pella, IW, USA). After incorporating for 2 to 4 weeks, organic rice was drill-seeded from late April to early May, depending on the weather conditions. The average dry biomass of Durana white clover (Trifolium repens), annual ryegrass (Lolium multiflorum), and fallow (volunteer weeds) were 4642,5613 , and $4020 \mathrm{~kg} \mathrm{ha}^{-1}$, respectively, in our 2012-2014 organic rice field trials (Table 2). Cover crops properties are shown in Table 3 and Table S1. Briefly, the crude protein, total $\mathrm{C}$, and total $\mathrm{N}$ were highest in clover, followed by C7R3 $(70 \%$ clover $+30 \%$ ryegrass) and fallow, and lowest in ryegrass. The C:N ratio was $<21$ in clover, C7R3, and fallow but $>21$ in C3R7 (30\% clover $+70 \%$ ryegrass) and ryegrass. The lignin: $\mathrm{N}$ ratio was highest in fallow, followed by ryegrass, and lowest in clover. The estimated index of net mineralization was $<1$ in all treatments. Cover crop crude protein and total nitrogen were determined by the high-temperature combustion process [42,45]. Lignin was determined using the Klason method [46]. Plant minerals, including P, K, Ca, Mg, Na, S, Zn, Fe, Cu, $\mathrm{Mn}$, and $\mathrm{B}$ were extracted using a nitric acid digest method and determined by ICP [47,48].

Table 2. Description of the cover crop biomass and organic rice yield in the 2012-2014 organic rice field trials.

\begin{tabular}{|c|c|c|c|c|c|}
\hline Cover Crop & $\begin{array}{l}\text { Cover Crop Seeding } \\
\text { Rate }\left(\mathrm{kg} \mathrm{ha}^{-1}\right)\end{array}$ & $\begin{array}{c}\text { Cover Crop Fresh } \\
\text { Biomass (kg } \\
\left.\text { ha }^{-1}\right)\end{array}$ & $\begin{array}{c}\text { Cover Crop } \\
\text { Moisture (\%) }\end{array}$ & $\begin{array}{c}\text { Cover Crop Dry } \\
\text { Biomass (kg } \\
\left.\text { ha }^{-1}\right)\end{array}$ & $\begin{array}{l}\text { Organic Rice } \\
\left.\text { Yield (kg ha }{ }^{-1}\right)\end{array}$ \\
\hline Fallow & 9 & 16,585 & 79.0 & 4020 & 7312 \\
\hline Clover & 9 & 20,999 & 77.8 & 4642 & 7443 \\
\hline Ryegrass & 9 & 25,400 & 75.8 & 5613 & 7292 \\
\hline
\end{tabular}

Table 3. Cover crop properties and soil microbial biomass C: $\mathrm{N}$ ratio.

\begin{tabular}{|c|c|c|c|c|c|c|c|c|c|}
\hline $\begin{array}{l}\text { Cover } \\
\text { Crop }\end{array}$ & $\begin{array}{l}\text { Crude Protein } \\
\quad\left(\mathrm{g} \mathrm{kg}^{-1}\right)\end{array}$ & $\begin{array}{l}\text { Lignin } \\
\left(\mathrm{g} \mathrm{kg}^{-1}\right)\end{array}$ & $\begin{array}{c}\text { Total C } \\
\left(\mathrm{g} \mathrm{kg}^{-1}\right)\end{array}$ & $\begin{array}{l}\text { Total N } \\
\left(\mathrm{g} \mathrm{kg}^{-1}\right)\end{array}$ & $\begin{array}{c}\mathrm{P} \\
\left(\mathrm{g} \mathrm{kg}^{-1}\right)\end{array}$ & $\begin{array}{c}\mathrm{K} \\
\left(\mathrm{g} \mathrm{kg}^{-1}\right)\end{array}$ & $\begin{array}{c}\text { Cover Crop } \\
\text { Lignin:N Ratio }\end{array}$ & $\begin{array}{l}\text { Cover Crop } \\
\text { C:N Ratio }\end{array}$ & $\begin{array}{c}\text { Soil Microbial } \\
\text { Biomass C:N Ratio }\end{array}$ \\
\hline Fallow & 110 & 120 & 341 & 17.6 & 3.2 & 28.6 & 6.8 & 19 & 14 \\
\hline Clover & 159 & 40 & 398 & 25.4 & 1.5 & 10.8 & 1.6 & 16 & 27 \\
\hline C7R3 * & 130 & 40 & 393 & 20.8 & 1.8 & 13.8 & 1.9 & 19 & 38 \\
\hline C3R7* & 92 & 40 & 385 & 14.6 & 2.2 & 17.7 & 2.7 & 26 & 43 \\
\hline Ryegrass & 63 & 40 & 380 & 10.0 & 2.5 & 20.7 & 4 & 38 & 52 \\
\hline
\end{tabular}




\subsection{Laboratory Incubation and Determinations}

A 31-day aerobic incubation experiment was conducted in 2019 using 1-L, wide-mouth jars arranged in a completely randomized design (CRD) with three replications. Three experimental factors included six cover crop mixtures [control, white clover, annual ryegrass, $70 \%$ clover $+30 \%$ ryegrass (C7R3), 30\% clover $+70 \%$ ryegrass (C3R7), and fallow (volunteer weeds)], five residue application rates (0, 0.6, 1.2, 1.8, and 2.4\%), and seven incubation times (D0, D1, D3, D7, D17, D24, and D31). Cover crops were freeze-dried, ground, and passed 0.5-mm sieve for use. Dry ground cover crop residues were added into $10.000 \mathrm{~g}$ dry soil according to the application rates $(w / w)$ ). We had 66 jars (no cover crop control $\times 6$ replications +5 cover crop mixtures $\times 4$ residue application rates $\times 3$ replications). Each jar contained one 50-mL centrifuge tube with $20 \mathrm{~mL}$ of $2 \mathrm{~mol} \mathrm{~L}^{-1} \mathrm{NaOH}$ for $\mathrm{CO}_{2}$ evaluation determination, one 50-mL glass beaker with soil and cover crop residue mixture for microbial biomass $\mathrm{C}$ and $\mathrm{N}$ determinations, four $50-\mathrm{mL}$ centrifuge tubes with soil and cover crop residue mixture for organic $\mathrm{C}$ and $\mathrm{N}$ as well as mineral $\mathrm{N}$ (ammonium, nitrite, nitrate) determinations, and one $25-\mathrm{mL}$ plastic vial with water to maintain humidity. In parallel, we had another 66 jars each containing a 50-mL glass beaker with soil and cover crop residue mixture as the unfumigated control for microbial biomass $\mathrm{C}$ and $\mathrm{N}$ determinations and a water vial to maintain humidity. Soils in all glass beakers and centrifuge tubes were adjusted to $50 \%$ of water holding capacity before incubation. The whole incubation lasted 31 days at $25^{\circ} \mathrm{C}$ using a Thermo Scientific incubator. During the incubation, water vials were checked routinely and refilled when necessary. Jars were opened at each sampling for 30 min to allow $\mathrm{O}_{2}$ exchange.

The $\mathrm{CO}_{2}$ evaluation during Day $0-1,1-3,3-7,7-17$, and 17-24 of incubation were measured at D1, D3, D7, D17, D24, respectively. At each sampling, the 50-mL centrifuge tube containing $20 \mathrm{~mL}$ of $2 \mathrm{~mol} \mathrm{~L}^{-1} \mathrm{NaOH}$ was replaced from each jar and covered with a lid immediately for titration. As a replacement, a new 50-mL centrifuge tube with $20 \mathrm{~mL} 2 \mathrm{~mol} \mathrm{~L}^{-1} \mathrm{NaOH}$ was put back into the jar after 30-min $\mathrm{O}_{2}$ exchange for a continuous incubation until the next sampling. At each sampling, 4 centrifuge tubes with $20 \mathrm{~mL}^{2} \mathrm{~mol} \mathrm{~L}^{-1} \mathrm{NaOH}$ were put in four jars without any samples as blank control, and another 4 centrifuge tubes with $20 \mathrm{~mL} 2 \mathrm{~mol} \mathrm{~L}^{-1} \mathrm{NaOH}$ were covered with lids as initial $\mathrm{NaOH}$ control and kept outside the incubator. A total of 74 centrifuge tubes with $\mathrm{NaOH}$ solution were taken out at each sampling for titration. The initial $\mathrm{NaOH}$ concentration and the $\mathrm{NaOH}$ left in each centrifuge tube were titrated with $2 \mathrm{~mol} \mathrm{~L}^{-1} \mathrm{HCl}$ with vigorous stirring in the presence of $\mathrm{BaCl}_{2}$ to a phenolphthalein endpoint. The $\mathrm{CO}_{2}$ evolution was calculated by subtracting the $\mathrm{CO}_{2}$ concentration in the blank control from the $\mathrm{CO}_{2}$ concentration in the jar with soil samples [25].

Soil mineral $\mathrm{N}$ contents $\left(\mathrm{NH}_{4}^{+}+\mathrm{NO}_{3}^{-}+\mathrm{NO}_{2}^{-}\right)$at D0 (background soil), D7, D17, D24 and D31 during incubation were determined. At each sampling, one centrifuge tube with soil and cover crop mixture was taken out from each jar, extracted with $40 \mathrm{~mL}$ $0.5 \mathrm{~mol} \mathrm{~L}^{-1} \mathrm{~K}_{2} \mathrm{SO}_{4}$, filtered with Whatman No. 2 filter paper, and determined for $\mathrm{NH}_{4}^{+}$, $\mathrm{NO}_{2}^{-}, \mathrm{NO}_{3}^{-}, \mathrm{pH}$, and EC. Soil $\mathrm{NH}_{4}^{+}$was measured using a BioTek microplate reader at $\mathrm{OD}_{660 \mathrm{~nm}}$ [49-51]. Soil $\mathrm{NO}_{2}^{-}$was measured with a BioTek microplate reader at $\mathrm{OD}_{550 \mathrm{~nm}}$, and $\mathrm{NO}_{3}^{-}$were first reduced to $\mathrm{NO}_{2}^{-}$using a $\mathrm{Cd}$ redactor and then measuring the concentration of $\mathrm{NO}_{2}^{-}[51,52]$. The relative nitrification index (RNI) at D0, D7, D17, D24, and D31 was estimated by calculating the proportion of the $\mathrm{NO}_{3}^{-}$to the sum of $\mathrm{NO}_{3}^{-}$and $\mathrm{NH}_{4}^{+}$[RNI $(\%)=\mathrm{NO}_{3}^{-} /\left(\mathrm{NO}_{3}^{-}+\mathrm{NH}_{4}^{+}\right) \times 100 \%$ ] according to Lavoie and Bradley [53] and Tian and Toda [54]. Soil pH was determined using a VWR Symphony B20PI Benchtop pH meter (VWR International, LLC., Radnor, PA, USA). Soil EC was determined using a Mettler Toledo EC meter (Mettler-Toledo, LLC, Columbus, OH, USA).

Dissolved organic C (DOC) and dissolved organic N (DON) in soils collected at D0 (Background soil), D7, D17, D24, and D31 were determined. The soil was extracted with $40 \mathrm{~mL} 0.5 \mathrm{~mol} \mathrm{~L}^{-1} \mathrm{~K}_{2} \mathrm{SO}_{4}$, shaken for $30 \mathrm{~min}$ on a shaker, centrifuged at $6000 \mathrm{rpm}$ for $10 \mathrm{~min}$, filtered through a GF/F $47 \mathrm{~mm} 100$ circles glass microfiber filter (Whatman, Cat 
No. 1825-047), and determined using a TOC- $\mathrm{V}_{\mathrm{CPH} / \mathrm{CPN}}$ analyzer (Shimadzu Corporation, Kyoto, Japan) following the manufacturer's instruction.

To determine soil microbial biomass $C$ (MBC) and microbial biomass $\mathrm{N}(\mathrm{MBN}), 132$ glass beakers with soil and cover crop mixture were taken out of incubation jars at D7. Soils in 66 glass beakers were fumigated with $\mathrm{CH}_{3} \mathrm{Cl}$ chloroform in the desiccator for $24 \mathrm{~h}$, and soils in the other 66 glass beakers were put in another desiccator and used as unfumigated control. At D8, both fumigated soil and unfumigated soil were extracted with $40 \mathrm{~mL} 0.5 \mathrm{~mol} \mathrm{~L}^{-1} \mathrm{~K}_{2} \mathrm{SO}_{4}$, shaken for $30 \mathrm{~min}$ on a shaker, centrifuged at $6000 \mathrm{rpm}$ for $10 \mathrm{~min}$, filtered through a GF/F $47 \mathrm{~mm} 100$ circles glass microfiber filter (Whatman, Cat No. 1825-047), and determined using a TOC- $\mathrm{V}_{\mathrm{CPH} / \mathrm{CPN}}$ analyzer (Shimadzu Corporation, Kyoto, Japan) following the manufacturer's manual. MBC and MBN were calculated using DOC and DON contents according to the equations reported by Beck et al. [55] and Brookes et al. [56].

Carbon use efficiency (CUE) was estimated using the equation: CUE $=\mathrm{MBC} /\left(\mathrm{CO}_{2}\right.$ evolution $\left.+\mathrm{MBC}\right)$ [57]. CUE is an assessment of the biological activity associated with the decomposition of residues and reflects the partitioning of $\mathrm{C}$ between microbial growth and respiration per unit of substrate organic $C$ consumed $[35,58]$. The greater the CUE, the greater the proportion of $C$ converted to biomass rather than respired. The index of net $\mathrm{N}$ mineralization was calculated using the equation: Index of net $\mathrm{N}$ mineralization $=$ cover crop C:N ratio $\times \mathrm{CUE} /$ microbial biomass C:N ratio [35]. Index value $>1$ means net $\mathrm{N}$ mineralization, otherwise net $\mathrm{N}$ immobilization [35].

\subsection{Soil Carbon and Nitrogen Mineralization Kinetics}

The observed soil cumulative $\mathrm{CO}_{2}$ evolution $\left(\mathrm{C}_{\min }\right)$ over $0,1,3,7,17$, and 24 days of incubation were fitted to a first-order kinetic model to estimate the amount of potentially mineralizable pool of $\mathrm{C}\left(\mathrm{C}_{0}\right)$ available for decomposers following residue additions (Equation (1)) [25,32,54,59]:

$$
\text { C mineralization, } \mathrm{C}_{\min }=\mathrm{C}_{0} \cdot\left(1-\exp \left(-k_{\mathrm{C}} \cdot t\right)\right)
$$

where $C_{\min }$ is the detected cumulative $C$ mineralization up to time $\left(\mathrm{mg} \mathrm{C} \mathrm{kg}^{-1}\right), \mathrm{C}_{0}$ is the $\mathrm{C}$ mineralization potential $\left(\mathrm{mg} \mathrm{C} \mathrm{kg}^{-1}\right), k$ is the decomposition rate constant $\left(\right.$ day $\left.^{-1}\right)$, and $t$ is the decomposition time (days). The decomposition rate constant $k_{C}$ describes the daily release of $C$ from the pool, which is proportional to the initial amount of cover crop residue amended and is inversely related to the residence time of the substrate and measures $C$ turnover period $[25,60]$.

The observed soil cumulative $\mathrm{CO}_{2}\left(\mathrm{C}_{\min }\right)$ and cover crop C:N ratio were used to estimate the $\mathrm{N}$ mineralization $\left(\mathrm{N}_{\min }\right)$ [54,61]. $\mathrm{N}_{\min }$ values were fitted to a first-order kinetics model Equation (2) to estimate the potentially mineralizable pool of $\mathrm{N}\left(\mathrm{N}_{0}\right)$ for decomposers following cover crop residue addition [25,30,54]:

$$
\mathrm{N} \text { mineralization, } \mathrm{N}_{\min }=\mathrm{N}_{0} \cdot\left(1-\exp \left(-k_{N} \cdot t\right)\right)
$$

where $\mathrm{N}_{\min }$ is the mineral $\mathrm{N}\left(\mathrm{mg} \mathrm{N} \mathrm{kg}^{-1}\right)$ detected in the soil after time $t$ (days); $\mathrm{N}_{0}$ is $\mathrm{N}$ mineralization potential $\left(\mathrm{mg} \mathrm{N} \mathrm{kg}^{-1}\right) ; k_{N}$ is the first-order rate constant $\left(\mathrm{day}^{-1}\right)$.

\subsection{Statistical Analysis}

Multivariate analysis of variance (MANOVA) was performed in R [62] to evaluate the effects of cover crop mixtures, residue application rate, and decomposition time on soil $\mathrm{CO}_{2}$ evolution, microbial biomass $\mathrm{C}$ and $\mathrm{N}$, dissolved organic $\mathrm{C}$ and $\mathrm{N}$, and mineral $\mathrm{N}$ contents $\left(\mathrm{NH}_{4}^{+}, \mathrm{NO}_{2}^{-}\right.$, and $\left.\mathrm{NO}_{3}^{-}\right)$. Mean separation was done using Tukey's multiple sample $t$-tests in R. All statistical tests were performed at a significance level of 0.05 . The non-linear regression model was used to estimate the model parameters in the first-order equations, including $C$ mineralization potential $\left(\mathrm{C}_{0}\right), \mathrm{N}$ mineralization potential $\left(\mathrm{N}_{0}\right), \mathrm{C}$ mineralization constant $\left(k_{C}\right), \mathrm{N}$ mineralization constant $\left(k_{N}\right)$, and half-lives of $\mathrm{C}$ and $\mathrm{N}$ mineralization $\left(t_{1 / 2}\right)$ 
based on the Gauss-Newton method with function "nls" in R [25,30]. Pearson's correlation coefficients $(r)$ between the observed and fitted values were computed.

\section{Results}

\subsection{Soil $\mathrm{CO}_{2}$ Evolution and the Estimation of Carbon (C) Mineralization}

Cumulative $\mathrm{CO}_{2}$ evolution was significantly $(p \leq 0.001)$ affected by the highest-ranking interaction of cover crop type $\times$ residue application rate $\times$ incubation time (Table 4). Cumulative $\mathrm{CO}_{2}$ evolution increased with increasing incubation time, and a rapid rate of $\mathrm{CO}_{2}$ evolution was detected in the first 7 days, whereas a relatively slow rate of $\mathrm{C}$ mineralization was detected during Day 7-24 for all treatments. Cumulative $\mathrm{CO}_{2}$ evolution linearly increased with increasing cover crop residue rate $\left(R^{2}>0.99\right)$ (Figure 1). The results suggested that the addition of cover crop residues significantly affected the cumulative $\mathrm{CO}_{2}$ evolution. Doubling the application rate of cover crop residues increased cumulative $\mathrm{CO}_{2}$ evolution by 1.2-1.4 times in all treatments. Of different cover crops, the cumulative $\mathrm{CO}_{2}$ evolution during 0-24 days was highest in soils amended with clover and 70\% clover + $30 \%$ ryegrass (C7R3), followed by $30 \%$ clover $+70 \%$ ryegrass (C3R7) and fallow, and lowest in ryegrass.

The observed $\mathrm{CO}_{2}$ evolution data from the laboratory incubation experiment were fitted into the first-order kinetic model to estimate the $C$ mineralization potentials $\left(C_{0}\right)$ and time required for mineralizing half of $\mathrm{C}_{0}\left(t_{1 / 2}\right)$. The $\mathrm{C}$ mineralization model fitted the observed data with Pearson's correlations $(r)$ between the observed and fitted values being larger than 0.985 for all treatments (Table 5), although this may be partly due to the limited number of sampling points. The $C$ mineralization potential $\left(\mathrm{C}_{0}\right)$ was highest in soils with diverse volunteer weeds in fallow (9069 $\mathrm{mg} \mathrm{kg}^{-1}$ ), followed by soils with the mixtures of clover and ryegrass (C7R3 $9228 \mathrm{mg} \mathrm{kg}^{-1}$, C3R7 $9232 \mathrm{mg} \mathrm{kg}^{-1}$ ), and lowest in soils with one cover crop (ryegrass $8638 \mathrm{mg} \mathrm{kg}^{-1}$, clover $8430 \mathrm{mg} \mathrm{kg}^{-1}$ ). The $\mathrm{C}_{0}$ was likely associated with the diversity of cover crops and the lignin: $\mathrm{N}$ ratio; soils with more diverse cover crops and higher lignin: $\mathrm{N}$ ratio tend to have higher $\mathrm{C}_{0}$. Interestingly, despite having the lowest $C_{0}$, clover had the fastest initial $C$ decomposition rate (1535 $\mathrm{mg} \mathrm{kg}^{-1}$ day $^{-1}$ ) and required the shortest time to approach half of the $\mathrm{C}_{0}$. Microbes in the control soil needed 17.2 days to mineralize half of $\mathrm{C}_{0}\left(4281 \mathrm{mg} \mathrm{C} \mathrm{kg}^{-1}\right)$, whereas they required 4.5 times shorter to decompose half of the $\mathrm{C}_{0}$ in soils with clover (8431 $\mathrm{mg} \mathrm{C} \mathrm{kg}^{-1}$ ).

Table 4. Significance of the interactions and main effects of cover crop (CC) type, cover crop residue application rate, and incubation time on the flush of $\mathrm{CO}_{2}$, soil organic and mineral $\mathrm{C}$ and $\mathrm{N}, \mathrm{pH}$, and $\mathrm{EC}$.

\begin{tabular}{|c|c|c|c|c|c|c|c|c|c|}
\hline & Cumulative $\mathrm{CO}_{2}$ & $\mathrm{NH}_{4}^{+}$ & $\mathrm{NO}_{2}^{-}$ & $\mathrm{NO}_{3}^{-}$ & TMN & DOC & DON & $\mathrm{pH}$ & EC \\
\hline CC Type & $\leq 0.001 * * *$ & $\leq 0.001 * * *$ & 0.222 & $\leq 0.001^{* * *}$ & $\leq 0.001 * * *$ & 0.010 * & $\leq 0.001^{* * *}$ & $\leq 0.001^{* * *}$ & $\leq 0.0001^{* * * *}$ \\
\hline CC Rate & $\leq 0.001 * * *$ & $\leq 0.001 * * *$ & 0.804 & $0.017 *$ & $0.001 * *$ & $\leq 0.001 * * *$ & $\leq 0.001 * * *$ & $0.005 * *$ & $\leq 0.0001 * * * *$ \\
\hline Incubation Time & $\leq 0.001 * * *$ & $\leq 0.001 * * *$ & 0.019 * & $\leq 0.001 * * *$ & $0.011 *$ & 0.925 & $\leq 0.001 * * *$ & $\leq 0.001 * * *$ & $\leq 0.001 * * *$ \\
\hline CC Type $\times$ CC Rate & $\leq 0.001 * * *$ & $\leq 0.001 * * *$ & 0.437 & 0.053 & $0.024 *$ & $0.033 *$ & $\leq 0.001^{* * *}$ & $\leq 0.001^{* * *}$ & $\leq 0.001 * * *$ \\
\hline $\begin{array}{c}\text { CC Type } \times \text { Incubation } \\
\text { Time }\end{array}$ & $\leq 0.001 * * *$ & $\leq 0.001 * * *$ & 0.238 & $\leq 0.001^{* * *}$ & $\leq 0.001^{* * *}$ & 0.670 & 0.450 & $\leq 0.001^{* * *}$ & 0.853 \\
\hline $\begin{array}{c}\text { CC Rate } \times \text { Incubation } \\
\text { Time }\end{array}$ & $\leq 0.001 * * *$ & $\leq 0.001^{* * *}$ & 0.761 & $\leq 0.001^{* * *}$ & $\leq 0.001^{* * *}$ & 0.143 & $0.005^{* *}$ & $0.003 * *$ & $0.005^{* *}$ \\
\hline $\begin{array}{c}\text { CC Type } \times \text { CC Rate } \times \\
\text { Incubation Time }\end{array}$ & $\leq 0.001 * * *$ & $\leq 0.001^{* * *}$ & 0.694 & $0.005^{* *}$ & $0.040 *$ & 0.564 & 0.717 & $0.003^{* *}$ & 0.718 \\
\hline
\end{tabular}

${ }^{*} p \leq 0.05,{ }^{* *} p \leq 0.01,{ }^{* * *} p \leq 0.001$, and ${ }^{* * * *} p \leq 0.0001$. TMN, total mineral N; DOC, dissolved organic C; DON, dissolved organic N. 

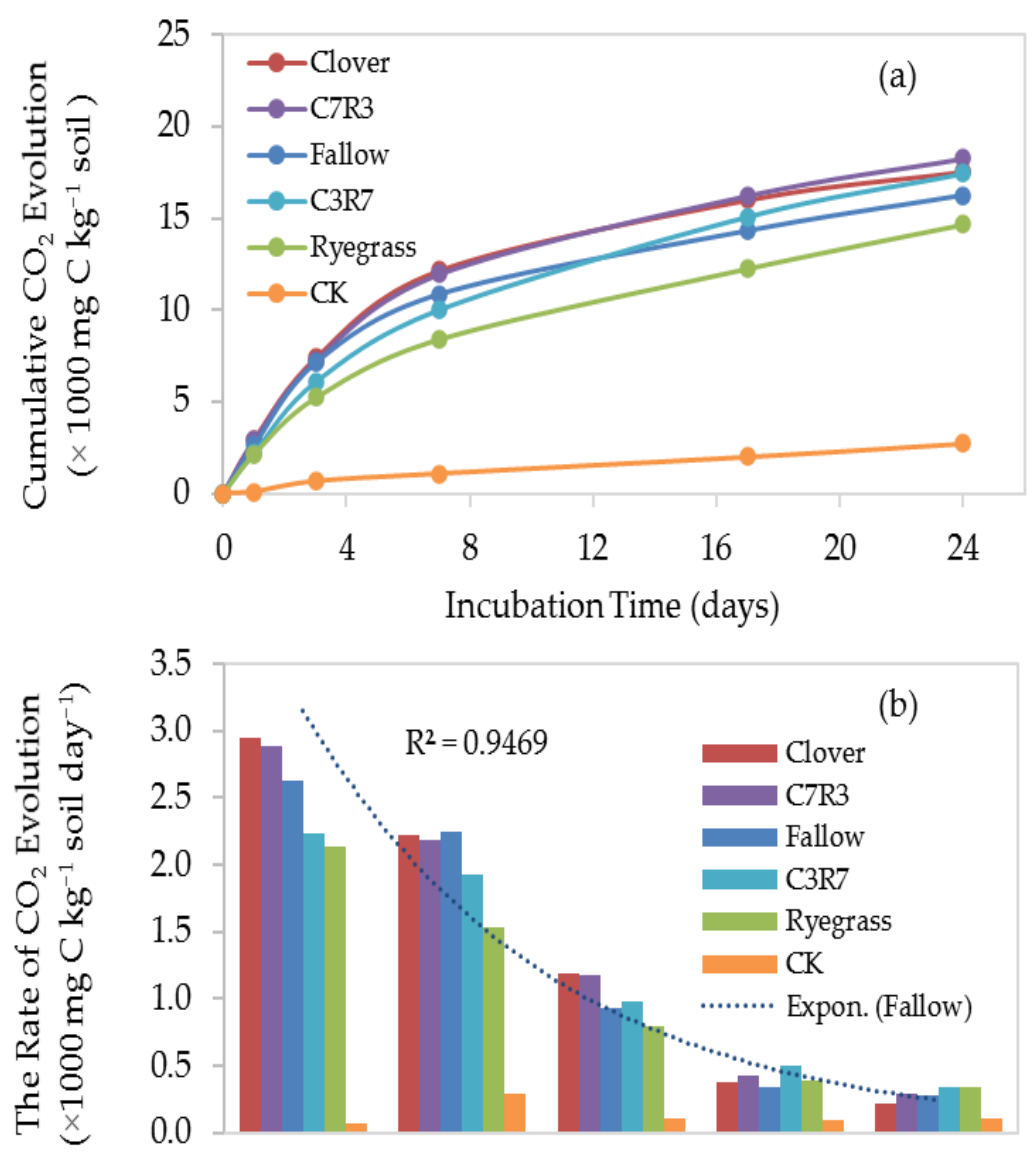

Day 0-1 Day 1-3 Day 3-7 Day 7-17 Day 17-24 Incubation Time Duration

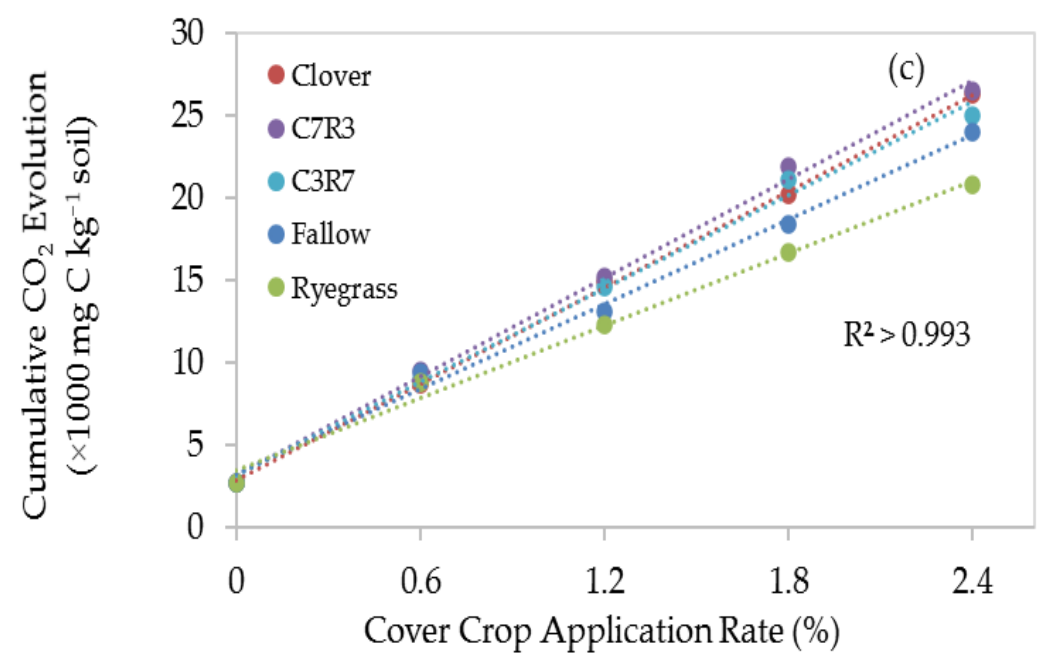

Figure 1. The cumulative $\mathrm{CO}_{2}\left(\mathrm{mg} \mathrm{C} \mathrm{g}^{-1}\right.$ soil) during (a) different times of incubation, (b) the cumulative $\mathrm{CO}_{2}$ during 0-24 d incubation of soils with different cover crop mixtures and residue application rates, and (c) the rate of $\mathrm{CO}_{2}$ evolution $\left(\mathrm{mg} \mathrm{C} \mathrm{g}^{-1}\right.$ soil day $\left.{ }^{-1}\right)$. Six cover crop mixtures included control (CK), white clover, annual ryegrass, $70 \%$ clover $+30 \%$ ryegrass (C7R3), 30\% clover $+70 \%$ ryegrass (C3R7), and fallow (volunteer weeds), five residue application rates included 0 , $0.6,1.2,1.8$, and $2.4 \%$, and five incubation times included $0-1,0-3,0-7,0-17$, and $0-24$ day with three replications. 
Table 5. Carbon $(\mathrm{C})$ and Nitrogen $(\mathrm{N})$ mineralization parameters during the $0-31$ day of incubation of soil amended with different cover crop mixtures.

\begin{tabular}{|c|c|c|c|c|c|c|c|}
\hline Model & $\begin{array}{l}\text { Cover } \\
\text { Crop }\end{array}$ & $\begin{array}{c}\text { Residue } \\
\text { Application } \\
\text { Rate (\%) }\end{array}$ & $\begin{array}{c}\text { Mineralization } \\
\text { Potential } \\
\left(\mathrm{C}_{0}, \mathrm{~N}_{0}\right)(\mathrm{mg} \\
\left.\mathrm{kg}^{-1}\right)\end{array}$ & $\begin{array}{c}\text { Mineralization } \\
\text { Rate } \\
\text { Constant } \\
\left(k_{\mathrm{C}}, k_{\mathrm{N}}\right) \\
\left(\text { day }^{-1}\right)\end{array}$ & $\begin{array}{c}\text { Initial Potential } \\
\text { Mineralization } \\
\text { Rate }\left(\mathrm{C}_{0} k c,\right. \\
\left.\mathrm{N}_{0} k_{N}\right)\left(\mathrm{mg} \mathrm{kg}^{-1}\right. \\
\left.\text { day }^{-1}\right)\end{array}$ & $\begin{array}{c}\text { Half-Life of } \\
\text { Mineraliza- } \\
\text { tion } \\
\left(t_{1 / 2}\right)(\text { day })\end{array}$ & $\begin{array}{c}\text { Correlation } \\
\text { Coefficient } \\
(r)\end{array}$ \\
\hline \multirow{6}{*}{$\begin{array}{c}\text { C Mineraliza- } \\
\text { tion Model } \\
\mathrm{C}_{\min }=\mathrm{C}_{0} \cdot(1 \\
-\exp \left(-k_{C} \cdot\right. \\
t))\end{array}$} & CK & 0 & 4281 & 0.040 & 172.9 & 17.2 & 0.987 \\
\hline & Fallow & 0.6 & 9069 & 0.145 & 1318.8 & 4.8 & 0.970 \\
\hline & Clover & 0.6 & 8430 & 0.182 & 1534.6 & 3.8 & 0.991 \\
\hline & Ryegrass & 0.6 & 8638 & 0.128 & 1102.6 & 5.5 & 0.970 \\
\hline & C7R3 & 0.6 & 9228 & 0.155 & 1433.5 & 4.5 & 0.985 \\
\hline & C3R7 & 0.6 & 9232 & 0.115 & 1063.7 & 6.0 & 0.987 \\
\hline \multirow{6}{*}{$\begin{array}{l}\text { N Mineraliza- } \\
\text { tion Model } \\
\mathrm{N}_{\min }=\mathrm{N}_{0} \cdot \\
\left(1-\exp \left(-k_{N}\right.\right. \\
\cdot t))\end{array}$} & CK & 0 & 911 & 0.040 & 36.8 & 17.2 & 0.993 \\
\hline & Fallow & 0.6 & 477 & 0.145 & 69.4 & 4.8 & 0.985 \\
\hline & Clover & 0.6 & 527 & 0.182 & 95.9 & 3.8 & 0.995 \\
\hline & Ryegrass & 0.6 & 227 & 0.128 & 29.0 & 5.4 & 0.985 \\
\hline & C7R3 & 0.6 & 486 & 0.155 & 75.4 & 4.5 & 0.992 \\
\hline & C3R7 & 0.6 & 355 & 0.115 & 40.9 & 6.0 & 0.993 \\
\hline
\end{tabular}

$\mathrm{C}_{\min }, \mathrm{C}$ mineralization estimated by $\mathrm{CO}_{2}$ evolution $\left(\mathrm{mg} \mathrm{kg}^{-1}\right) ; \mathrm{N}_{\min }, \mathrm{N}$ mineralization estimated by $\mathrm{CO}_{2}$ evolution/cover crop C:N ratio $\left(\mathrm{mg} \mathrm{kg}^{-1}\right) ; \mathrm{C}_{0}, \mathrm{C}$ mineralization potential $\left(\mathrm{mg} \mathrm{kg}^{-1}\right) ; \mathrm{N}_{0}, \mathrm{~N}$ mineralization potential $\left(\mathrm{mg} \mathrm{kg}^{-1}\right) ; k_{\mathrm{C}}, \mathrm{C}$ mineralization rate constant $\left(\mathrm{day}^{-1}\right)$; $k_{\mathrm{N}}, \mathrm{N}$ mineralization rate constant $\left(\mathrm{day}^{-1}\right) ; \mathrm{C}_{0} k_{\mathrm{C}}$ initial potential $\mathrm{N}$ mineralization rate; $\mathrm{N}_{0} k_{\mathrm{N}}$ initial potential $\mathrm{N}$ mineralization rate; $t_{1 / 2}$, time for mineralization of half of $\mathrm{C}_{0}$ or $\mathrm{N}_{0} ; r$, the correlation coefficient between model fitted values and observed values.

\subsection{Estimation of $N$ Mineralization Potential $\left(N_{0}\right)$ and Half-Life $\left(t_{1 / 2}\right)$}

Soil $\mathrm{CO}_{2}$ evolution during $\mathrm{C}$ mineralization and cover crop $\mathrm{C}: \mathrm{N}$ ratio were used to describe the $\mathrm{N}$ mineralization $\left(\mathrm{N}_{\min }\right)$ by fitting into a first-order model to estimate the $\mathrm{N}$ mineralization potential $\left(\mathrm{N}_{0}\right)$ and half-life $\left(t_{1 / 2}\right)$ (Table 5). The models fitted the observed data in all treatments with correlation coefficients $(r)$ between the observed and fitted values being larger than 0.985 . Although the control had a good $\mathrm{N}$ mineralization potential $\left(\mathrm{N}_{0}\right)$, its $\mathrm{N}$ mineralization half-life $\left(t_{1 / 2}\right)$ was $2.9-4.5$ times longer than soils amended with cover crops. Of cover crops, clover had the greatest $\mathrm{N}_{0}$, the largest mineralization rate constant $\left(k_{\mathrm{N}}\right)$, the fastest initial potential mineralization rate $\left(\mathrm{N}_{0} k_{\mathrm{N}}\right)$, and the shortest time to mineralize half of the $\mathrm{N}_{0}$. Based on the model, clover needed 3.8 days to mineralize $264 \mathrm{mg} \mathrm{N} \mathrm{kg}^{-1}, \mathrm{C} 7 \mathrm{R} 3$ and fallow needed $4.5-4.8$ days to mineralize $239-243 \mathrm{mg} \mathrm{N} \mathrm{kg}^{-1}$, while C3R7 and ryegrass needed 5.4-6.0 days to mineralize as little as $114-178 \mathrm{mg} \mathrm{N} \mathrm{kg}^{-1}$.

The total observed $\mathrm{N}$ in the microbial pool, dissolved organic pool, and inorganic pool $(\mathrm{MBN}+\mathrm{DON}+\mathrm{TMN})$ and its correlation with estimated $\mathrm{N}$ mineralization $\left(\mathrm{N}_{\min }\right)$ is shown in Figure 2. The total observed $\mathrm{N}$ had a strong correlation with estimated $\mathrm{N}$ mineralization in all treatments (Figure $2 a, b)$. The total observed $N$ linearly $\left(R^{2}>0.930\right)$ increased with increasing cover crop residue application rate in all treatments except ryegrass (Figure 2c). It is surprising that the total observed $\mathrm{N}$ only accounted for $<10 \%$ of the total estimated $\mathrm{N}$ mineralization. The results suggested that the microbial $\mathrm{C}$ use efficiency could be lower than we imagined and the mineralized $\mathrm{N}$ loss through $\mathrm{N}_{2} \mathrm{O}$ emission and/or $\mathrm{NH}_{3}$ volatilization could be more than we expected. The $\mathrm{C}$ use efficiency ranged from $5.21-8.97 \%$ for soils amended with cover crops in this study (Table S2). 

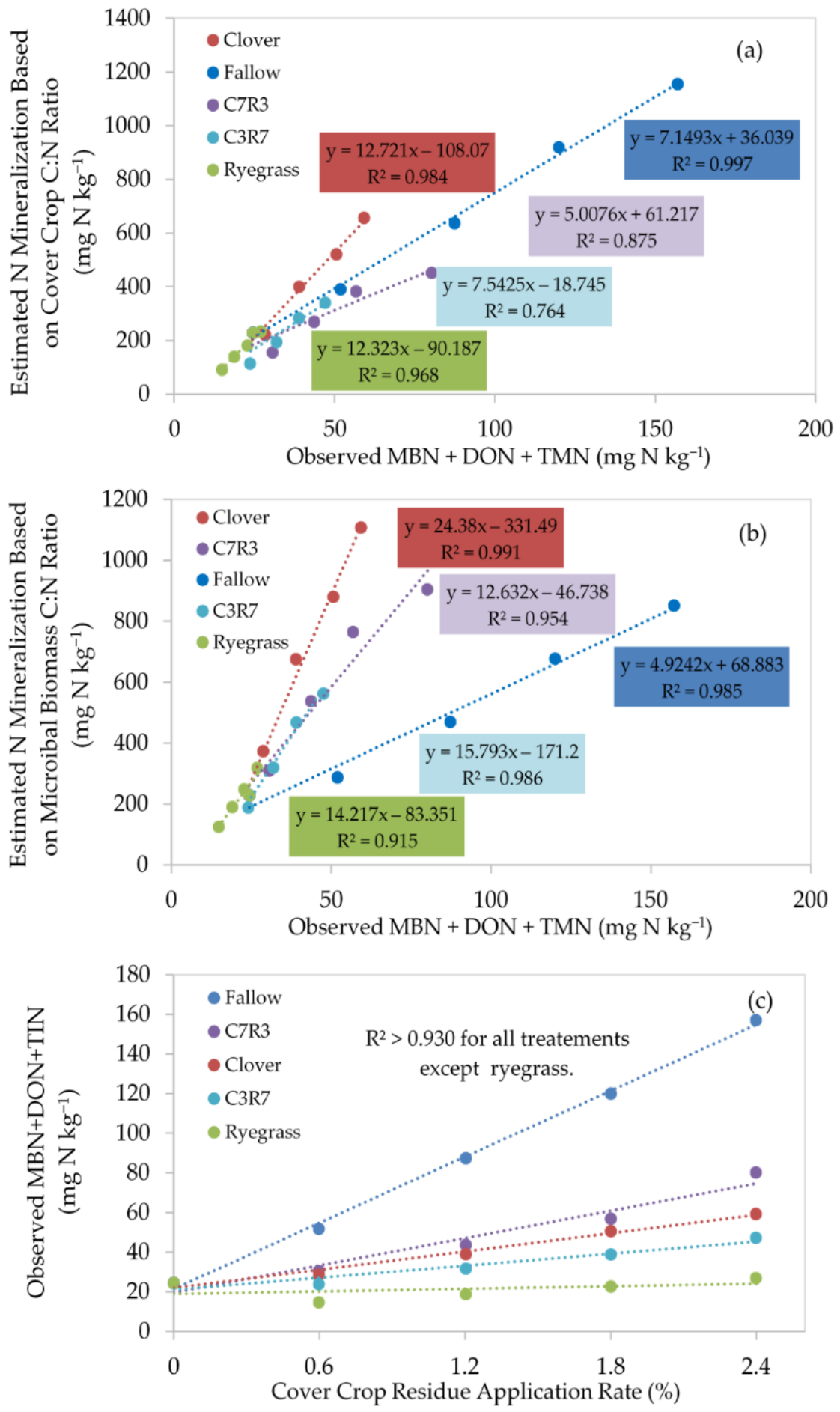

Figure 2. Relationship between estimated $\mathrm{N}$ mineralization $\left(\mathrm{mg} \mathrm{N} \mathrm{kg}^{-1}\right)$ and observed $\mathrm{MBN}+\mathrm{DON}$ $+\mathrm{TMN}\left(\mathrm{mg} \mathrm{N} \mathrm{kg}^{-1}\right.$ ) at Day 7. $\mathrm{N}$ mineralization potential was estimated by (a) C mineralization/ cover crop C:N ratio and (b) C mineralization/ microbial biomass C:N ratio, respectively. (c) The observed MBN + DON + TMN in soils with different cover crop mixtures and residue application rates. Six cover crop mixtures included control (no cover crop added), white clover, annual ryegrass, $70 \%$ clover $+30 \%$ ryegrass (C7R3), 30\% clover $+70 \%$ ryegrass (C3R7), and fallow (volunteer weeds), five residue application rates included $0,0.6,1.2,1.8$, and $2.4 \%$. MBN, microbial biomass N; DON, dissolved organic $\mathrm{N}$; TMN, total mineral $\mathrm{N}$. 


\subsection{Soil $\mathrm{C}$ and $N$ in Microbial and Organic Pools}

Soil microbial biomass $\mathrm{C}(\mathrm{MBC})$ and microbial biomass $\mathrm{N}(\mathrm{MBN})$ were significantly affected by the interaction of cover crop type $\times$ application rate $(p \leq 0.001)$ (Table 4$)$. Both MBC and MBN linearly increased with increasing cover crop residue rate $\left(R^{2}>0.96\right)$ (Figure 3). Among different cover crop types, fallow with diverse volunteer weeds had the greatest $\mathrm{MBC}$, followed by the mixtures of clover and ryegrass, and least in ryegrass and clover. $\mathrm{MBC}$ is likely associated with cover crop diversity and lignin: $\mathrm{N}$ ratio; it was higher in soils with more diverse cover crops and higher in soils amended with high lignin: $\mathrm{N}$ ratio cover crop mixtures. Microbial biomass $\mathrm{N}$ was greatest in fallow, followed by C7R3 and clover, and lowest in ryegrass. MBN is likely associated with cover crop diversity and C:N ratio; it was higher in soils amended with more diverse cover crops and higher in soils amended with low C:N ratio cover crop mixtures. The ratio of soil MBC:MBN was higher than the ratio of cover crop material C:N in all treatments but fallow (Table 3), which suggested that not all organic materials in cover crop were readily decomposable. Nevertheless, it is consistent that fallow or clover had the lowest C:N ratios, followed by the mixes of clover and ryegrass, and lowest in ryegrass.
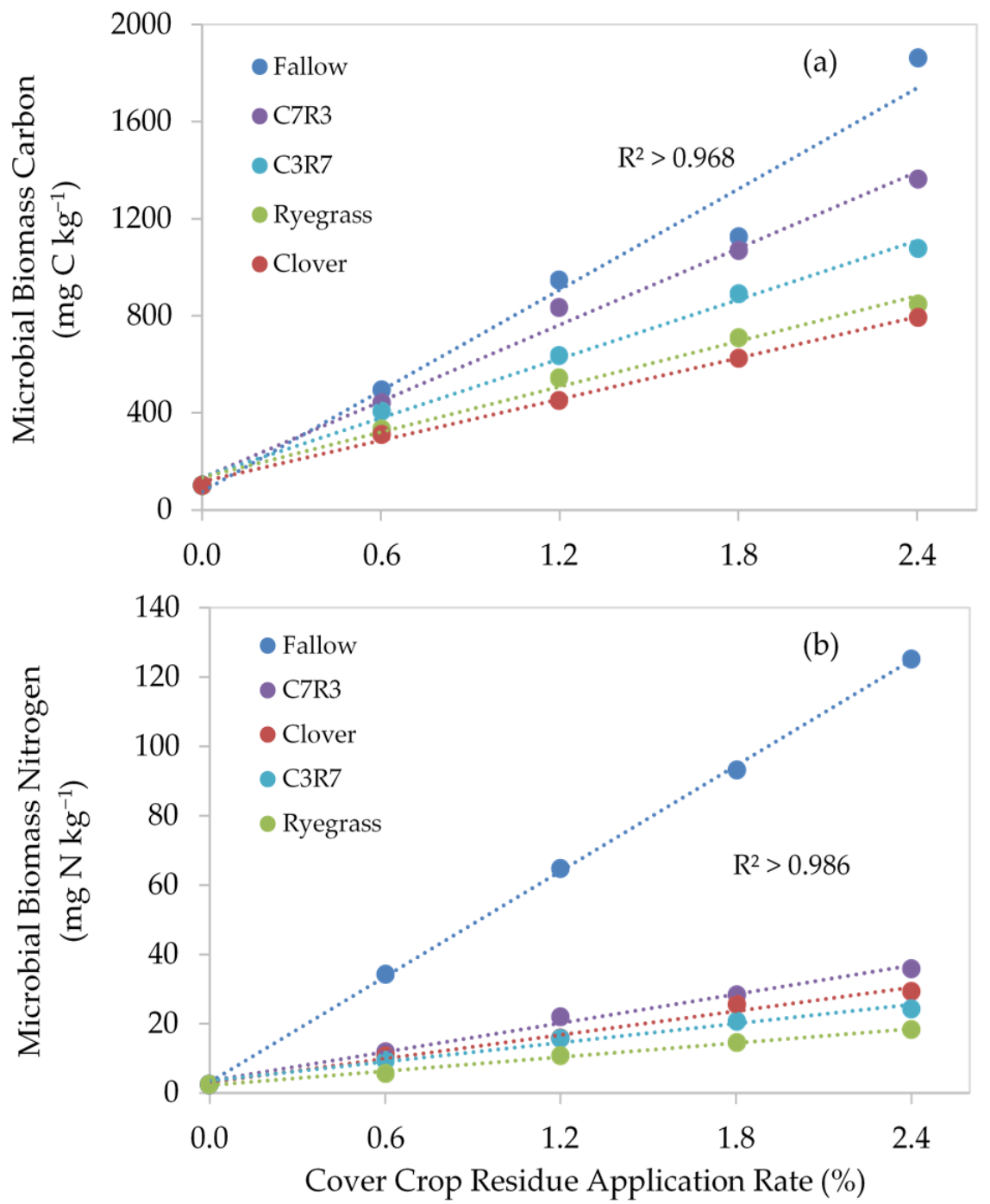

Figure 3. Soil microbial biomass carbon (a) and microbial biomass nitrogen (b) under different cover crop residue mixtures and application rates. Six cover crop mixtures included control (no cover crop added), white clover, annual ryegrass, $70 \%$ clover $+30 \%$ ryegrass (C7R3), 30\% clover $+70 \%$ ryegrass (C3R7), and fallow (volunteer weeds), five residue application rates included 0, 0.6, 1.2, 1.8, and 2.4\%. 
Soil dissolved organic C (DOC) was significantly affected by the interaction of cover crop type $\times$ application rate $(p \leq 0.05)$ (Table 4$)$. Compared to the control, soils amended with cover crops increased DOC contents with a higher content detected in soils with a higher application rate. The DOC in soils with high application rates $(1.8 \%$ and $2.4 \%)$ increased rapidly in the first 7 days then decreased gradually during 7-31 days. By contrast, DOC in soils with low application rates $(0,0.6 \%$, and $1.2 \%)$ was relatively stable with incubation. Nevertheless, DOC contents in incubated soils were higher than that in background soil. Soil dissolved organic $N$ (DON) was significantly impacted by the interactions of cover crop type $\times$ application rate $(p \leq 0.001)$ and application rate $\times$ incubation time $(p \leq 0.01)$ (Table 4$)$. Compared to the control, cover crops amendment increased soil DON with a higher DON detected in soils with higher residue application rate. In the no cover crop control, soil DON increased with increasing incubation time, whereas the trends in soils with different cover crops were variable depending on the cover crop C:N ratio. In soils with low C: $\mathrm{N}$ ratio cover crops (clover, C7R3, and fallow), soil DON increased with time and peaked at D17, then decreased with time. In soils with relatively high C:N ratio cover crops (C3R7 and Ryegrass), soil DON was even lower than control during this experimental time range.

\subsection{Soil Mineral Nitrogen Availability}

Soil total mineral nitrogen (TMN) content during the 31-day incubation was significantly affected by the interaction of cover crop type $\times$ residue application rate $\times$ incubation time (Table 4). The dynamic of soil total mineral $\mathrm{N}$ during 0-31 days in soils amended with different cover crop mixtures and application rates is shown in Figure 4. Soil TMN in all treatments temporarily decreased at the initial stage of incubation when compared to the control, except for clover 2.4\%, C7R3 2.4\%, and fallow 2.4\%. After a temporary decrease, TMN at residue application rate $0.6 \%$ lead the increase in TMN and required the shortest time to reach the crossover point $\left(t_{c}\right)$, at which the amount of TMN in soils amended with cover crop equaled that of the control soil (Figure 4). At $0.6 \%$, the TMN in soils amended with clover, C7R3, and fallow started gradually increasing at Day 17. The result indicated that, during Day 0-17, the mineral $\mathrm{N}$ released by mineralization was less than the mineral $\mathrm{N}$ consumed by immobilization, while a net mineral $\mathrm{N}$ release was observed after Day 17. At $0.6 \%$, clover needed 27 days to reach the crossover point. Clover needed the shortest time to start providing mineral $\mathrm{N}$ for organic rice use, followed by C7R3 and fallow, and C3R7 and ryegrass required the longest time to start providing mineral $\mathrm{N}$ to rice plants (Figure 4).

Of mineral $\mathrm{N}, \mathrm{NH}_{4}^{+}$and $\mathrm{NO}_{3}^{-}$are plant available $\mathrm{N}$. During 0-31 days of aerobic incubation, nitrification occurred, which was evidenced by the dominance of $\mathrm{NH}_{4}^{+}$before incubation and the dominance of $\mathrm{NO}_{3}^{-}$after incubation (Figure 5). Soil $\mathrm{NH}_{4}^{+}$concentration generally decreased with increasing incubation time, while $\mathrm{NO}_{3}^{-}$concentration generally increased with increasing incubation time. The relative nitrification index (RNI), the proportion of the $\mathrm{NO}_{3}^{-}$to the sum of $\mathrm{NO}_{3}^{-}$and $\mathrm{NH}_{4}^{+}$, increased with incubation time. Both $\mathrm{NH}_{4}^{+}$and $\mathrm{NO}_{3}^{-}$, increased linearly $\left(\mathrm{R}^{2}>0.89\right)$ with increasing cover crop residue rate, except the soils with ryegrass. Of different cover crops, $\mathrm{NH}_{4}^{+}$content was highest in soils amended with C7R3 or fallow, followed by clover, and lowest in ryegrass. The trend of RNI of different cover crop mixtures can be divided into three groups: RNI in control increased rapidly in the first 7 days but relatively slow during Day 7-31; RNI in soils with low C:N ratio cover crop types (clover, C7R3, and fallow) increased slowly in the first 7 days but rapidly during 7-31 days, and the fastest increase was observed during Day 17-24; and RNI in soils with high C:N ratio cover crop types (C3R7 and ryegrass) increased slowly during the first 17 days but rapidly during Day 17-31, and the fastest increase was observed during Day 24-31. 


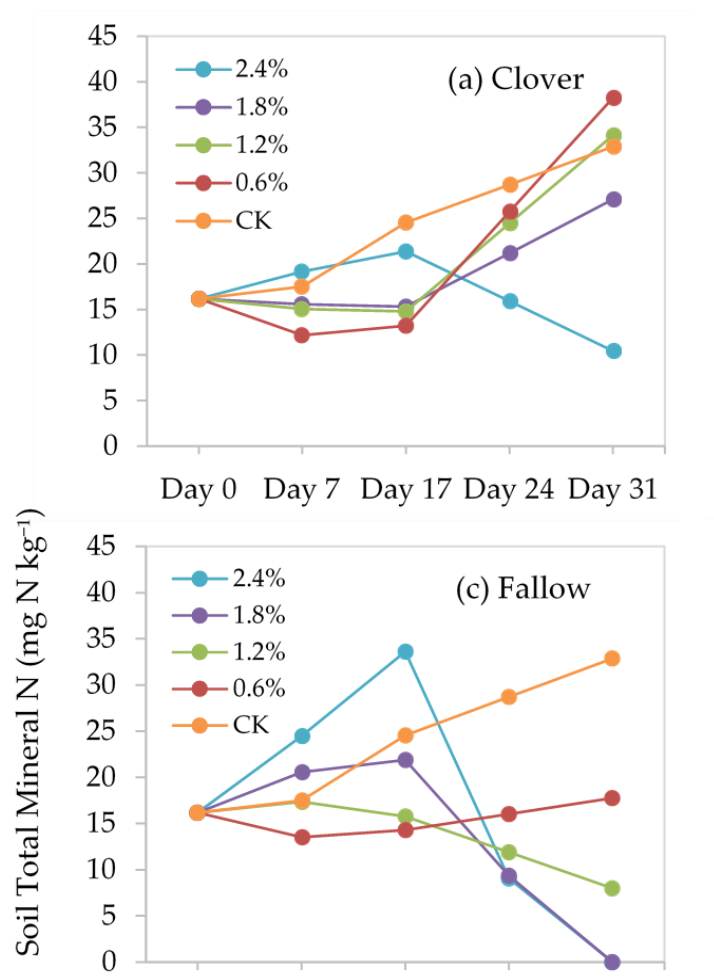

Day 0 Day 7 Day 17 Day 24 Day 31

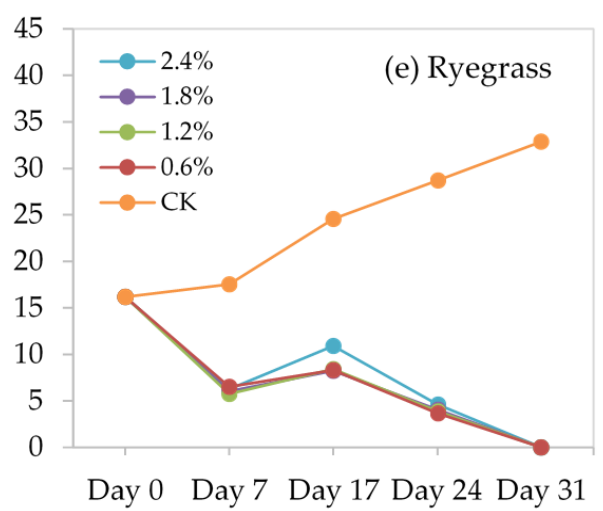

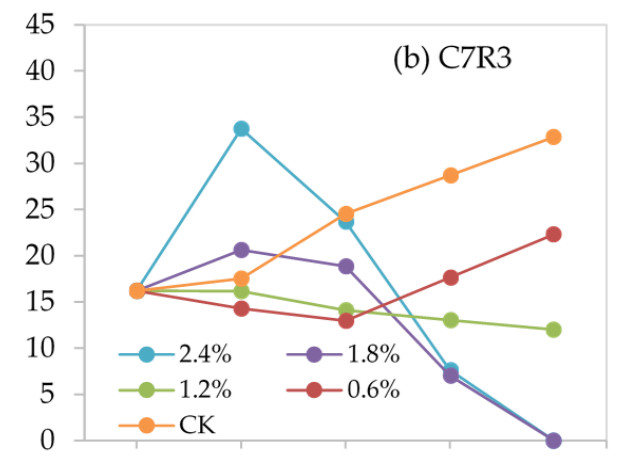

Day 0 Day 7 Day 17 Day 24 Day 31

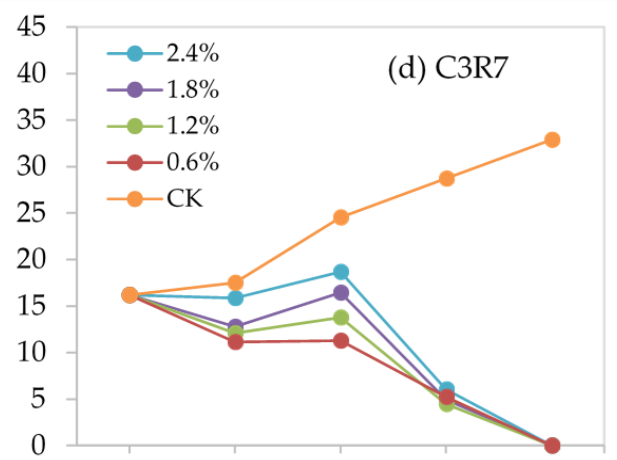

Day 0 Day 7 Day 17 Day 24 Day 31

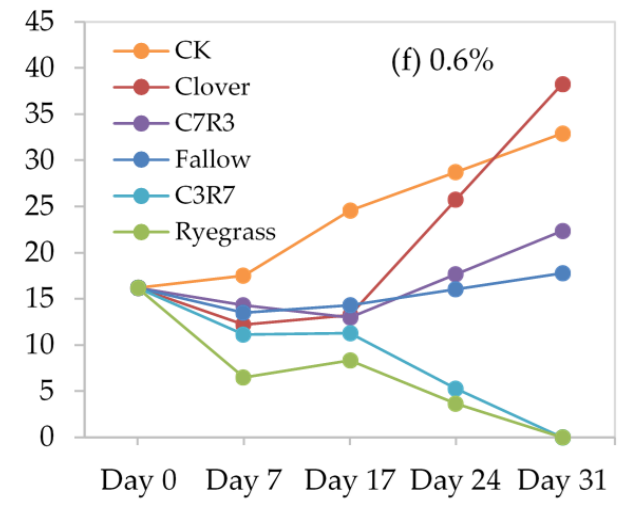

Sampling Time

Figure 4. Dynamics of soil total mineral $\mathrm{N}$ during 0-31 day in soils with different cover crop mixtures and application rates. (a) Total mineral $\mathrm{N}$ in soils with clover at different application rates; (b) total mineral $\mathrm{N}$ in soils with $70 \%$ clover $+30 \%$ ryegrass (C7R3) at different application rates; (c) total mineral $\mathrm{N}$ in soils with fallow (volunteer weeds) at different application rates; (d) total mineral $\mathrm{N}$ in soils with $30 \%$ clover $+70 \%$ ryegrass (C3R7) at different application rates; (f) total mineral $\mathrm{N}$ in soils with different cover crop mixtures at the residue application rate of $0.6 \%$. Six cover crop mixtures included control (CK), white clover, annual ryegrass, $70 \%$ clover $+30 \%$ ryegrass (C7R3), 30\% clover + $70 \%$ ryegrass (C3R7), and fallow (volunteer weeds), five residue application rates included 0, 0.6, 1.2, 1.8 , and $2.4 \%$. 


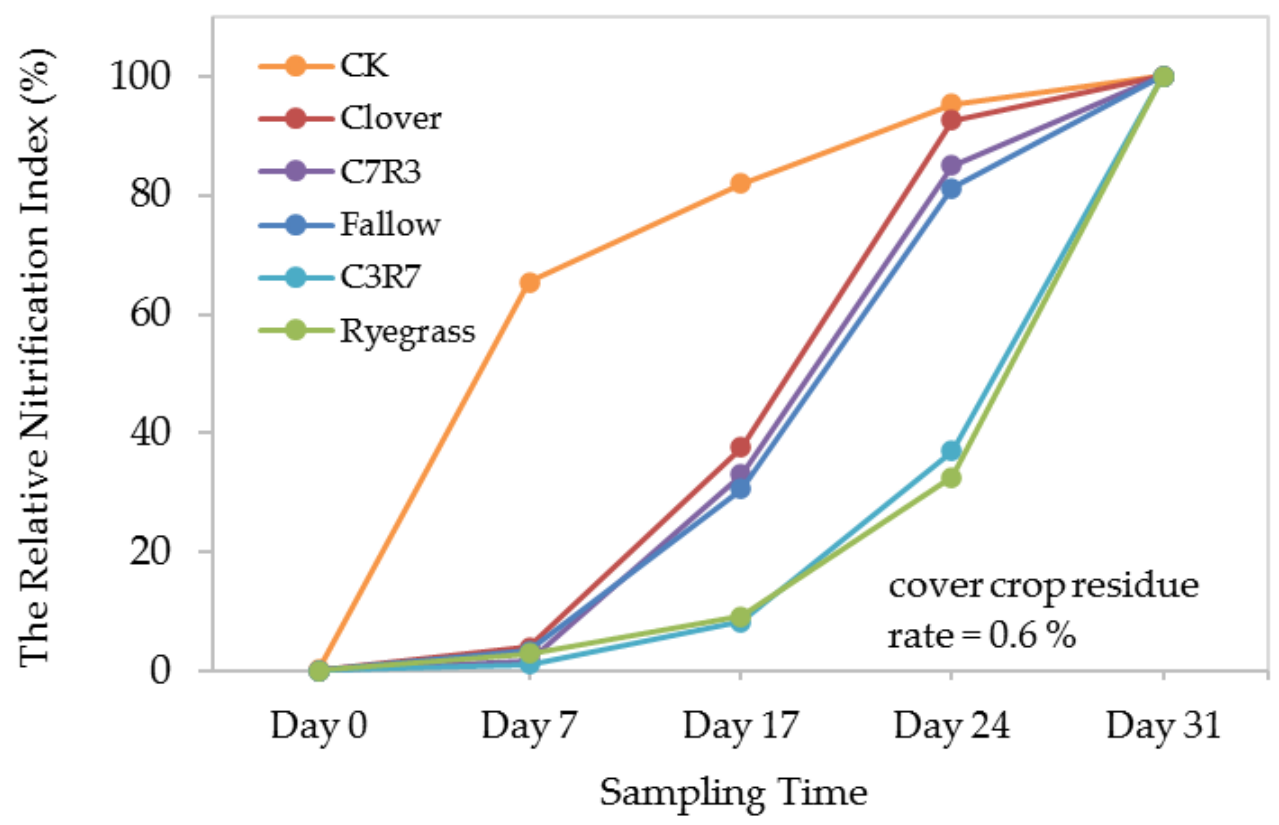

Figure 5. The relative nitrification index (RNI) during 0-31 day in soils with different cover crop mixes at the optimal residue application rate of $0.6 \%$. RNI was estimated by $\mathrm{RNI}(\%)=\mathrm{NO}_{3}^{-} /\left(\mathrm{NO}_{3}^{-}+\right.$ $\left.\mathrm{NH}_{4}^{+}\right) \times 100 \%$ according to Lavoie and Bradley [53] and Tian and Toda [54]. Six cover crop mixtures included control (CK), white clover, annual ryegrass, $70 \%$ clover $+30 \%$ ryegrass (C7R3), 30\% clover + 70\% ryegrass (C3R7), and fallow (volunteer weeds), and five sampling times included Day 0, Day 7, Day 17, Day 24, and Day 31.

\section{Discussion}

\subsection{Carbon and Nitrogen Mineralization under Different Cover Crops and Application Rates}

Soil $\mathrm{CO}_{2}$ evolution is a sensitive indicator of microbial decomposition of cover crop residue [25], in which $\mathrm{CO}_{2}$ is released from decomposing nutrients contained in soil organic matter to mineral forms by soil microbes and respiration from plant roots and soil fauna. We observed that cumulative $\mathrm{CO}_{2}$ evolution increased with increasing incubation time with a rapid evolution rate detected in the first 7 days and a relatively slow rate in the following days (Figure 1). The result suggested that the rapid breakdown of organic matter (organic acids, amino acids, and simple sugars) majorly occurred during 0-7 days and the $\mathrm{C}$ mineralization gradually decreased during 7-24 days. The results aligned with previous studies $[25,61,63]$, which also reported a rapid increase at the initial stage and a relatively slower increase at the following stage. In these studies, however, the time duration of the initial rapid increase varied from one to two weeks depending on cover crop types, application rates, and soil types. Trinsoutrot et al. [59] interpreted that the initial decomposition rate was strongly related to the presence of soluble compounds, and the relationship between $C$ mineralized and soluble fractions weakened as decomposition proceeded.

$C$ mineralization varied among cover crop types and residue application rates (Figure 1, Table 5). Generally, plant residues with a low C:N ratio decompose faster than residues with a high C:N ratio [13,21-24,64]. In this study, clover, C7R3, and fallow had a lower C:N ratio when compared to C3R7 and ryegrass (Table 3). Wagger et al. [65] found increasing the plant residues C:N ratio from 28 to 37 increased net $\mathrm{N}$ immobilization from 12 to $33 \%$. However, Carvalho et al. reported that the $\mathrm{C}: \mathrm{N}$ ratio alone does not represent well the microbial decomposition because it does not take the quality of $C$ into consideration [66]. The recalcitrant fraction of $\mathrm{SOC}$, such as lignin, cellulose, etc. decomposed slowly and produced a small $\mathrm{CO}_{2}$ flux over a long time [67]. Numerous studies reported that cover crop decomposition rate was positively correlated with plant residue quality $[23,64,68]$. Tian et al. proposed a concept of plant residue quality index (PRQI) and reported that it was higher in cover crops with a low $\mathrm{C}: \mathrm{N}$ ratio and 
low lignin content [68]. Silva et al. also observed a faster decomposition rate in soils with residues containing a high concentration of $\mathrm{N}$ and low lignin and polyphenol contents [64].

$\mathrm{N}$ mineralization and $\mathrm{C}$ mineralization are correlated and can be estimated by soil $\mathrm{CO}_{2}$ evolution and cover crop C: $\mathrm{N}$ ratio [54,61]. Although $\mathrm{N}$ mineralization potential $\left(\mathrm{N}_{0}\right)$ in the control was estimated to be as high as $911 \mathrm{mg} \mathrm{N} \mathrm{kg}^{-1}$, it would require 2.9-4.5 times longer to mineralize half of the $\mathrm{N}_{0}$. Adding cover crops into soil increased the mineralization rate constant by 2.9-4.6 times, increased the initial potential mineralization rate by 1.1-2.6 times, and shortened the half-life of mineralization $\left(t_{1 / 2}\right)$ by 2.9-4.5 times. Of cover crop types, clover showed the best performance in $\mathrm{N}$ mineralization to maximize the $\mathrm{N}$ availability in the shortest time. The promotion of mineralization by cover crops amendment was also observed by Ghimire et al. [25].

\subsection{Effect of Cover Crop Types and Application Rates on Microbial Biomass Carbon and Nitrogen}

Soil microorganisms are the key players in decomposing organic matter to mineral forms that are available to crops [69], and microbial biomass $C$ can be used to assess the biological activity associated with the decomposition of residues using the equation: carbon use efficiency $(\mathrm{CUE})=\mathrm{MBC} /\left(\mathrm{CO}_{2}\right.$ evolution $\left.+\mathrm{MBC}\right)[35,57,58]$. The greater the CUE is, the greater the proportion of substrate organic $\mathrm{C}$ converted to microbial biomass rather than respired. In this study, the CUE ranged 5.21-8.97\%, and was highest in fallow, followed by two mixtures, and lowest in clover (Table S2). CUE varied across conditions, especially soil moisture and temperature [38]. The low CUE also explained why the total observed $\mathrm{N}$ in the microbial pool, dissolved organic pool, and inorganic pool (MBN + DON + TMN) was only $10 \%$ or less of the total $\mathrm{N}$ mineralization potential (Table 5, Figure 2).

Microbial biomass $\mathrm{C}(\mathrm{MBC})$ is likely associated with cover crop diversity and lignin:N ratio; it was higher in soils with more diverse cover crops and higher in soils amended with high lignin:N ratio cover crops (Figure 3). The relationship between soil microbial biomass and cover crop diversity was also observed by Gentsch et al. [70], who reported that the microbial biomass contents were highest in soils with 12 cover crop mixes, followed by soils with 4 cover crop mixes, and lowest in soils with one cover crop. Lignin is a complex aromatic polymer and typically presents at $15-25 \%$ in lignocellulosic, which is the 2 nd most abundant renewable and sustainable $C$ source [71]. Lignin and $N$ content as predictors of litter decay rates, and low lignin: $\mathrm{N}$ ratio is expected to lead to a higher decomposition rate [60]. In this study, the cover crop initial lignin:TN was highest in fallow, followed by ryegrass and two mixtures, and lowest in clover (Table 3).

Microbial biomass $\mathrm{N}(\mathrm{MBN})$ is likely affected by cover crop diversity and C:N ratio; it was higher in soils with more diverse cover crops and higher in soils amended with low C:N ratio cover crops (Figure 3). Microbial decomposition is an extraordinarily complex process. It is, however, generally agreed that soil microbes have an average $\mathrm{C}: \mathrm{N}$ ratio of 7-8; only about $1 / 3$ of $C$ used by microbes is incorporated into their cells (MBC) and the remaining $2 / 3$ is used as an energy source and respired as $\mathrm{CO}_{2}$ through a series of reactions $\left([\mathrm{C}, \mathrm{O}, 4 \mathrm{H}]+\mathrm{O}_{2} \rightarrow \mathrm{CO}_{2}+2 \mathrm{H}_{2} \mathrm{O}+\right.$ energy). Thus, microbes need at least 21 parts of $\mathrm{C}$ for every part of $\mathrm{N}$ assimilated. In this study, when cover crops with low $\mathrm{C}: \mathrm{N}$ ratio (clover, fallow, and C7R3) were added into soil, cover crop residue potentially provides plenty of $\mathrm{N}$ for microbial growth. Microbes 'attack' cover crop residue for their growth and lead to an increase in microbial abundance and diversity, which was evidenced by the increased microbial biomass $\mathrm{C}$ and $\mathrm{N}$. The thrived microbes digest organic residues to complex amino compounds (aminization: organic residues/proteins $+\mathrm{O}_{2} \rightarrow$ complex amino compounds $+\mathrm{CO}_{2}+$ energy + other products). When sufficient $\mathrm{C}$ is available, the complex amino compounds can only be used in the synthesis of new cellular material. When the cover crop $\mathrm{C}: \mathrm{N}$ ratio is low and $\mathrm{C}$ is not enough for microbes to incorporate all complex amino compounds into cellular structure, the extra complex amino acids $\left(\mathrm{R}-\mathrm{NH}_{2}\right)$ will be mineralized to produce energy and $\mathrm{NH}_{3}$ byproduct (ammonification: $\mathrm{R}-\mathrm{NH}_{2}+$ $\mathrm{HOH} \rightarrow \mathrm{R}-\mathrm{OH}+\mathrm{NH}_{3}+$ energy). Depending on the $\mathrm{pH}$ and temperature, $\mathrm{NH}_{4}^{+}$will be formed $(\mathrm{pH}<7)$ and released to the soil $\left(2 \mathrm{NH}_{3}+\mathrm{H}_{2} \mathrm{CO}_{3} \leftarrow \rightarrow\left(\mathrm{NH}_{4}\right)_{2} \mathrm{CO}_{3} \leftarrow \rightarrow 2 \mathrm{NH}_{4}^{+}+\right.$ 
$\mathrm{CO}_{3}^{2-}$ ). With the presence of $\mathrm{O}_{2}$ during incubation, $\mathrm{NH}_{4}^{+}$is nitrified and $\mathrm{NO}_{3}^{-}$is formed to produce more energy $\left(\mathrm{NH}_{4}^{+}+1.5 \mathrm{O}_{2} \rightarrow \mathrm{H}_{2} \mathrm{O}+2 \mathrm{H}^{+}+\right.$energy, $\mathrm{NO}_{2}^{-}+0.5 \mathrm{O}_{2} \rightarrow \mathrm{NO}_{3}^{-}+$ energy). The occurrence of nitrification in this study was also supported by the results of relative nitrification index (RNI) in this study (Figure 5). When cover crops with a high C:N ratio (C3R7 and ryegrass) were added into soil, cover crop residue could not provide sufficient $\mathrm{N}$ for microbes to use all $\mathrm{C}$ in the residue to support microbial growth. In order to use $\mathrm{C}$ in the cover crop residue to produce energy and form cell structure (i.e., protein), microbes have to 'rob' mineral $\mathrm{N}$ from soil: $\mathrm{NH}_{4}^{+}$and / or $\mathrm{NO}_{3}^{-} \rightarrow \mathrm{R}-\mathrm{NH}_{2}$ (immobilization) and lead to a temporary decrease in soil total inorganic $\mathrm{N}$.

\subsection{Soil Mineral N Availability under Different Cover Crop Types and Application Rates}

A temporary decrease in soil total mineral nitrogen (TMN) content was detected in all treatments at the initial stage of incubation. The results indicated that immobilization occurred not only in soils with high C:N ratio cover crops (ryegrass and C3R7), but also in soils with low C:N ratio cover crops (clover, C7R3, and fallow). It suggested that cover crop materials with low $\mathrm{C}: \mathrm{N}$ ratio are not always readily decomposable, since not all organic molecules are easily degraded. The cover crop C:N ratio is more a qualitative rather than a quantitative measure of substrate quality and the relative availability of $\mathrm{C}$ and $\mathrm{N}$. If a considerable amount of $C$ in cover crop residue is in the form of lignin or other resistant materials, the actual C: $\mathrm{N}$ ratio could be larger, which has been evidenced by the higher microbial biomass C:N ratio compared to cover crop C:N ratio (Table 3). The index of net $\mathrm{N}$ mineralization was calculated using the equation: Index of net $\mathrm{N}$ mineralization $=$ cover crop C:N ratio * CUE/ microbial biomass $\mathrm{C}: \mathrm{N}$ ratio [35]. An index value $>1$ indicated net $\mathrm{N}$ mineralization and an index value $<1$ indicated net $\mathrm{N}$ immobilization [35]. In this study, the index of net $\mathrm{N}$ mineralization was $<1$ in all treatments at D7 (Table S2), which explained why a temporary decrease in soil mineral $\mathrm{N}$ was detected at the initial stage of incubation. A similar trend was also observed in previous laboratory incubation studies and field trials $[72,73]$, which reported that plant-available $\mathrm{N}\left(\mathrm{NH}_{4}^{+}+\mathrm{NO}_{3}^{-}\right)$was higher in control than soils with cover crops at the beginning of incubation, but the trend reversed after 20-30 days of incubation. The temporary decrease could be attributed to the $\mathrm{N}$ immobilization related to rapid microbial growth and $\mathrm{N}$ assimilation, denitrification caused by increased microbial activity, and increased $\mathrm{NH}_{3}$ volatilization during residue degradation [30,74]. Net immobilization of $\mathrm{N}$ took place during early decomposition with residue $\mathrm{C}: \mathrm{N}$ as low as 15-21 in the initial weeks [72,75]. Mineral N, especially in the form of $\mathrm{NH}_{4}^{+}$, is supposed to be the primary source for immobilization [76]). In the absence of $\mathrm{NH}_{4}^{+}, \mathrm{NO}_{3}^{-}$was shown to be a good substrate for microbial assimilation [77]. The decrease in $\mathrm{NH}_{4}^{+}$and increase in $\mathrm{NO}_{3}^{-}$in this study also supported the observations about a temporary decrease in TMN caused by immobilization (Figure 5 ).

After a temporary decrease, TMN in clover at residue application rate $0.6 \%$ showed an increase in TMN earliest compared to other residue rates and needed the shortest time to reach the crossover point (Figure 4). The results indicated that, after the incorporation of clover into soils, producers are needed to wait at least 27 days for organic rice planting to allow microbial decomposition to start supplying mineral $\mathrm{N}$ to the soil. When the time between cover crop incorporation and rice planting is too short, the soil TMN could be lower than the control. In this case, instead of providing $\mathrm{N}$ for organic rice, microbial immobilization can compete with rice regarding soil mineral N. Compared to the control, clover needed the shortest time while ryegrass required the longest time to start providing mineral $\mathrm{N}$ to the following crop (Figure 4). Kuo and Sainju reported that the time needed for soils amended with ryegrass to reach a crossover point was 30 weeks [30].

In practice, it is important to select the appropriate cover crop type, rate, and termination time. Of the cover crop types and rates tested, clover at $0.6 \%$ provided the greatest mineral $\mathrm{N}$ and required the shortest time to mineralize half of the $\mathrm{N}$ mineralization potential $\left(\mathrm{N}_{0}\right)$. In our 2012-2014 organic rice field trials, the average annual clover dry biomass was $4642 \mathrm{~kg} \mathrm{ha}^{-1}$ (Table 2). Assuming the soil weight is 1,820,000 kg dry soil ha-1 
( $15 \mathrm{~cm}$ deep, bulk density $1.2 \mathrm{~g} \mathrm{~cm}^{-3}$ ), the residue application rate of $0.6 \%$ would be $10,920 \mathrm{~kg} \mathrm{ha}^{-1}$ dry biomass in the organic field. A seeding rate of $9 \mathrm{~kg} \mathrm{ha}^{-1}$ was used to achieve $4642 \mathrm{~kg} \mathrm{ha}^{-1}$ dry biomass in the organic field; thus, a seeding rate of $21 \mathrm{~kg} \mathrm{ha}^{-1}$ clover seed and a minimum of 27 days between cover crop incorporation and planting would be needed to maximize the mineral $\mathrm{N}$ availability for rice growth at an early stage.

\section{Conclusions}

Incorporation of cover crops into soil can offer an effective way to increase mineral nitrogen $(\mathrm{N})$ for organic rice growth. Cover crop $\mathrm{C}$ mineralization increased with increasing incubation time with a rapid mineralization rate detected in the first 7 days and a relatively slow rate detected in the following days. The addition of cover crop residues significantly increased the cumulative $C$ mineralization, which linearly increased with increasing cover crop residue rate. Of different cover crop types, clover or mixtures of clover and ryegrass had the greatest cumulative $\mathrm{C}$ mineralization, followed by fallow, and the lowest in ryegrass. Clover had the greatest $\mathrm{N}$ mineralization potential and initial $\mathrm{N}$ mineralization rates, and required the shortest time to decompose half of the $\mathrm{N}$ mineralization potential $\left(\mathrm{N}_{0}\right)$. Based on the observed and modeling results, clover is the optimal cover crop type, $0.6 \%$ is the optimal residue application rate, and a minimum of 27 days is required between cover crop termination and rice planting to provide mineral $\mathrm{N}$ for organic rice growth. The results indicated that adoption of clover at $0.6 \%$ (seeding rate $21 \mathrm{~kg} \mathrm{ha}^{-1}$, dry biomass $10,920 \mathrm{~kg} \mathrm{ha}^{-1}$ ) and incorporation of cover crop at least 27 days before seeding organic rice could be a promising strategy to improve soil mineral $\mathrm{N}$ availability and reduce fertilizer cost. The results of this study provide a great addition to the toolbox for decision-makers, researchers, county agents, and producers to adjust $\mathrm{N}$ application to more precisely match crop $\mathrm{N}$ demand and make improved organic adoption and management decisions. Still, further studies are needed to validate the results under field conditions in different soil types, at various locations, under other climate conditions, and associated with varying varieties of rice to ensure the success of organic rice production.

Supplementary Materials: The following are available online at https:/ /www.mdpi.com/2071-105 0/13/5/2866/s1, Table S1: Micronutrient contents of the cover crops, Table S2: Carbon use efficiency and index of net mineralization in soils amended with different cover crops.

Author Contributions: All authors provided critical feedback and helped shape the research, analysis, and manuscript. Conceptualization, X.L. and F.D.; methodology, X.L. and F.D.; software, K.C., Y.P. and X.L.; validation, X.L. and T.G.; formal analysis, X.L., K.C. and Y.P.; investigation, X.L. and A.T.; resources, F.D.; data curation, X.L. and F.D.; writing—original draft preparation, X.L. and F.D.; writing-review and editing, all authors; visualization, X.L.; supervision, F.D.; project administration, F.D.; funding acquisition, F.D. All authors have read and agreed to the published version of the manuscript.

Funding: This research was funded by the National Institute of Food and Agriculture, U.S. Department of Agriculture (USDA) (grant number 2012-51106-20137) and USDA Southern Sustainable Agriculture Research and Education Program (LS 12-249).

Conflicts of Interest: The authors declare no conflict of interest.

\section{References}

1. USDA-ERS. Organic Production. Table 3. Certified Organic and Total U.S. Acreage, Selected Crops and Livestock, 1995-2011 (Last Updated on 24 October 2013). Economic Research Service, United States Department of Agriculture. Available online: https: / / www.ers.usda.gov / data-products / organic-production/ (accessed on 16 July 2020).

2. USDA-NASS. Certified Organic Survey 2016 Summary Report (Released on 20 September 2017). National Agriculture Statistics Service, United States Department of Agriculture. Available online: https:/ / downloads.usda.library.cornell.edu/usda-esmis/ files/zg64tk92g/70795b52w/4m90dz33q/OrganicProduction-09-20-2017_correction.pdf (accessed on 16 July 2020).

3. Jerkins, D.; Ory, J. National Organic Research Agenda: Outcomes and Recommendations from the 2015 National Organic Farmer Survey and Listening Sessions. 2016. Available online: https://ofrf.org/wp-content/uploads/2019/09/NORA_2016_final9_28. pdf (accessed on 27 May 2020). 
4. Robertson, G.P.; Vitousek, P.M. Nitrogen in agriculture: Balancing the cost of an essential resource. Annu. Rev. Environ. Resour. 2009, 34, 97-125. [CrossRef]

5. Claire, C.; John, D.L.; Bill, D.; Laura, L.V.E. Legume cover crop management on nitrogen dynamics and yield in grain corn systems. Field Crops Res. 2017, 201, 75-85.

6. Sainju, U.M.; Singh, H.P.; Singh, B.P.; Whitehead, W.F.; Chiluwal, A.; Paudel, R. Cover crop and nitrogen fertilization influence soil carbon and nitrogen under bioenergy sweet sorghum. Agron. J. 2018, 110, 463-477. [CrossRef]

7. Ritter, W.F.; Scarborough, R.W.; Chirnside, A.E.M. Winter cover crops as a best management practice for reducing nitrogen leaching. J. Contam. Hydrol. 1998, 34, 1-15. [CrossRef]

8. Shelton, R.E.; Jacobsen, K.L.; McCulley, R.L. Cover crops and fertilization alter nitrogen loss in organic and conventional conservation agriculture systems. Front. Plant Sci. 2018, 8, 2260. [CrossRef] [PubMed]

9. Thapa, R.; Mirsky, S.B.; Tully, K.L. Cover crops reduce nitrate leaching in agroecosystems: A global meta-analysis. J. Environ. Qual. 2018, 47, 1400-1411. [CrossRef] [PubMed]

10. Reberg-Horton, S.C.; Burton, J.D.; Danehower, D.A.; Ma, G.; Monks, D.W.; Murphy, J.P.; Ranells, N.N.; Williamson, J.D.; Creamer, N.G. Changes over time in the allelochemical content of ten cultivars of rye (Secale cereale L.). J. Chem. Ecol. 2005, 31, 179-193. [CrossRef]

11. Cordeau, S.; Guillemin, J.P.; Reibel, C.; Chauvel, B. Weed species differ in their ability to emerge in no-till systems that include cover crops. Ann. Appl. Biol. 2015, 166, 444-455. [CrossRef]

12. Schipanski, M.E.; Barbercheck, M.; Douglas, M.R.; Finney, D.M.; Haider, K.; Kaye, J.P.; Kemanian, A.R.; Mortensen, D.A.; Ryan, M.R.; Tooker, J.; et al. A framework for evaluating ecosystem services provided by cover crops in agroecosystems. Agric. Syst. 2014, 125, 12-22. [CrossRef]

13. Finney, D.M.; White, C.M.; Kaye, J.P. Biomass production and carbon/nitrogen ratio influence ecosystem services from cover crop mixtures. Agron. J. 2016, 108, 39-52. [CrossRef]

14. Cook, J.C.; Gallagher, R.S.; Kaye, J.P.; Lynch, J.; Bradley, B. Optimizing vetch nitrogen production and corn nitrogen accumulation under no-till management. Agron. J. 2010, 102, 1491-1499. [CrossRef]

15. White, K.E.; Brennan, E.B.; Cavigelli, M.A.; Smith, R.F. Winter cover crops increase readily decomposable soil carbon, but compost drives total soil carbon during eight years of intensive, organic vegetable production in California. PLoS ONE 2020, 15, e0228677. [CrossRef]

16. Dabney, S.M.; Breitenbeck, G.A.; Griffin, J.L.; Hoff, B.J. Subterranean clover cover crop used to increase rice yield. Agron. J. 1989, 81, 483-487. [CrossRef]

17. Yu, Y.; Xue, L.; Yang, L. Winter legumes in rice crop rotations reduces nitrogen loss, and improves rice yield and soil nitrogen supply. Agron. Sustain. Dev. 2014, 34, 633-640. [CrossRef]

18. Luo, M.; Wang, Z.; Yang, B.; Zheng, L.; Yao, Z.; Seyrek, U.A.; Chung, H.; Wei, H. Effects of winter cover crops on rice pests, natural enemies, and grain yield in a rice rotation system. J. Insect. Sci. 2019, 19, 1-8. [CrossRef] [PubMed]

19. Correia, S.L.; Silva, P.R.F.; Boeni, M.; Bredemeier, C.; Anghinoni, I.; Menegati, G.B.; Maass, M.B.; Miozzo, L.C. Performance of flooded rice grown in succession to winter cover crops. Rev. Bras. Cienc. Solo. 2018, 42, e0160461. [CrossRef]

20. Portugal, J.R.; Arf, O.; Buzetti, S.; Portugal, A.R.P.; Garcia, N.F.S.; Meirelles, F.C.; Garé, L.M.; Abrantes, F.L.; Rodrigues, R.A.F. Do cover crops improve the productivity and industrial quality of upland rice? Agron. J. 2020, 112, 327-343. [CrossRef]

21. Kuo, S.; Huang, B.; Bembenek, R. Effect of winter cover crops on soil nitrogen availability, corn yield, and nitrate leaching. Sci. World J. 2001, 1 (Suppl. S2), 22-29. [CrossRef] [PubMed]

22. Jahanzad, E.; Barker, A.V.; Hashemi, M.; Eaton, T.; Sadeghpour, A.; Weis, S.A. Nitrogen release dynamics and decomposition of buried and surface cover crop residue. Agron. J. 2016, 108, 1735-1741. [CrossRef]

23. Lynch, M.J.; Mulvaney, M.J.; Hodges, S.C.; Thompson, T.L.; Thomason, W.E. Decomposition, nitrogen and carbon mineralization from food and cover crop residues in the central plateau of Haiti. Springerplus 2016, 5, 973-981. [CrossRef] [PubMed]

24. White, C.M.; Finney, D.M.; Kemanian, A.R.; Kaye, J.P. A model-data fusion approach for predicting cover crop nitrogen supply to corn. Agron. J. 2016, 108, 2527-2540. [CrossRef]

25. Ghimire, B.; Ghimire, R.; VanLeeuwen, D.; Mesbah, A. Cover crop residue amount and quality effects on soil organic carbon mineralization. Sustainability 2017, 9, 2316. [CrossRef]

26. Thorup-Kristensen, K.; Dresbøll, D.B. Incorporation time of nitrogen catch crops influences the N effect for the succeeding crop. Soil Use Manag. 2010, 26, 27-35. [CrossRef]

27. Vigil, M.F.; Kissel, D.E. Rate of nitrogen mineralized from incorporated crop residues as influenced by temperature. Soil Sci. Soc. Am. J. 1995, 59, 1636-1644. [CrossRef]

28. Chaves, B.; De Neve, S.; Hofman, G.; Boeckx, P.; Van Cleemput, O. Nitrogen mineralization of vegetable root residues and greenmanures as related to their (bio)chemical composition. Eur. J. Agron. 2004, 21, 161-170. [CrossRef]

29. Frankenberger, W.T., Jr.; Abdelmagid, H.M. Kinetic parameters of nitrogen mineralization rates from leguminous crops incorporated into soil. Plant Soil 1985, 87, 257-271. [CrossRef]

30. Kuo, S.; Sainju, U.M. Nitrogen mineralization and availability of mixed leguminous and non-leguminous cover crop residues in soil. Biol. Fertil. Soil 1998, 26, 346-353. [CrossRef]

31. Melkonian, J.; Poffenbarger, H.J.; Mirsky, S.B.; Ryan, M.R.; Moebius-Clune, B.N. Estimating nitrogen mineralization from cover crop mixtures using the precision nitrogen management model. Agron. J. 2017, 109, 1944-1959. [CrossRef] 
32. Breland, T.A. Enhanced mineralization and denitrification as a result of heterogeneous distribution of clover residues in soil. Plant Soil 1994, 166, 1-12. [CrossRef]

33. Dou, F.; Zhou, X.; McClung, A.; Storlien, J.; Lang, Y.; Torbert, A.; Hons, F.; Wards, B.; Kresovich, S.; Wight, J. Cover crop, Soil amendments, and variety effects on organic rice production in Texas. In Proceedings of the 35th The Rice Technical Working Group Meeting, New Orleans, LA, USA, 18-21 February 2014; p. 141.

34. Dou, F.; Anderson, D.; Kresovich, S.; McClung, A.; Ward, B.; Zhou, X. Improving Soil Quality to Increase Yield and Reduce Diseases in Organic Rice Production; Final Report for USDA SARE Grant LS12-249; USDA: College Park, MD, USA, 2015. Available online: https: / / projects.sare.org/project-reports/1s12-249/ (accessed on 20 September 2020).

35. O'Connell, S.; Shi, W.; Grossman, J.M.; Hoyt, G.D.; Fager, K.L.; Creamer, N.G. Short-term nitrogen mineralization from warmseason cover crops in organic farming systems. Plant Soil 2015, 396, 353-367. [CrossRef]

36. Zibilske, L.M.; Bradford, J.M. Oxygen effects on carbon, polyphenols, and nitrogen mineralization potential in soil. Soil Sci. Soc. Am. J. 2007, 71, 133-139. [CrossRef]

37. Wang, C.; Wan, S.; Xing, X.; Zhang, L.; Han, X. Temperature and soil moisture interactively affected soil net $\mathrm{N}$ mineralization in temperate grassland in Northern China. Soil Biol. Biochem. 2006, 38, 1101-1110. [CrossRef]

38. Pold, G.; Domeignoz-Horta, L.A.; Morrison, E.W.; Frey, S.D.; Sistla, S.A.; DeAngelis, K.M. Carbon use efficiency and its temperature sensitivity covary in soil bacteria. mBio 2020, 11, e02293-19. [CrossRef] [PubMed]

39. Martin, J.V.; de Imperial, R.M.; Calvo, R.; Garcia, M.C.; Leon-Cofreces, C.; Delgado, M.M. Carbon mineralization kinetics of poultry manure in two soils. Soil Res. 2012, 50, 222-228. [CrossRef]

40. Schofield, R.K.; Taylor, A.W. The measurement of soil pH. Soil Sci. Soc. Am. Proc. 1955, 19, 164-167. [CrossRef]

41. Rhoades, J.D. Soluble salts. In Methods of Soil Analysis: Part 2. Agronomy Monograph 9, 2nd ed.; Page, A.L., Ed.; ASA: Madison, WI, USA; SSSA: Madison, WI, USA, 1982; pp. 167-178.

42. McGeehan, S.L.; Naylor, D.V. Automated instrumental analysis of carbon and nitrogen in plant and soil samples. Commun. Soil Sci. Plant Anal. 1988, 19, 493-505. [CrossRef]

43. Mehlich, A. New extractant for soil test evaluation of phosphorus, potassium, magnesium, calcium, sodium, manganese, and zinc. Commun. Soil Sci. Plant Anal. 1978, 9, 477-492. [CrossRef]

44. Mehlich, A. Mehlich-3 soil test extractant: A modification of Mehlich-2 extractant. Commun. Soil Sci. Plant Anal. 1984, 15, 1409-1416. [CrossRef]

45. Sweeney, R.A. Generic combustion method for determination of crude protein in feeds: Collaborative Study. J. Assoc. Off. Anal. Chem. 1989, 72, 770-774. [CrossRef]

46. Dence, C.W. The determination of lignin. In Methods in Lignin Chemistry; Lin, S.Y., Dence, C.W., Eds.; Springer: Heidelberg, Germany, 1992; pp. 33-61.

47. Isaac, R.A.; Johnson, W.C. Collaborative study of wet and dry ashing techniques for the elemental analysis of plant tissue by atomic absorption spectrophotometry. J. Assoc. Off. Anal. Chem. 1975, 58, 436-440. [CrossRef]

48. Havlin, J.L.; Soltanpour, P.N. A nitric acid and plant digest method for use with inductively coupled plasma spectrometry. Commun. Soil Sci. Plant Anal. 1989, 14, 969-980. [CrossRef]

49. Dorich, R.A.; Nelson, D.W. Direct colorimetric measurement of ammonium in potassium chloride extracts of soil. Soil Sci. Soc. Am. J. 1983, 47, 833-836. [CrossRef]

50. Markus, D.K.; McKinnon, J.P.; Buccafuri, A.F. Automated analysis of nitrite, nitrate, and ammonium nitrogen in soils. Soil Sci. Soc. Am. J. 1985, 49, 1208-1215. [CrossRef]

51. Kachurina, O.M.; Zhang, H.; Raun, W.R.; Krenzer, E.G. Simultaneous determination of soil aluminum, ammonium- and nitrate-nitrogen using $1 \mathrm{M}$ potassium chloride extraction. Commun. Soil Sci. Plant Anal. 2000, 31, 893-903. [CrossRef]

52. Keeney, D.R.; Nelson, D.W. Nitrogen-Inorganic forms. In Methods of Soil Analysis: Part 2. Agronomy Monograph 9, 2nd ed.; Page, A.L., Miller, R.H., Keeney, D.R., Eds.; ASA: Madison, WI, USA; SSSA: Madison, WI, USA, 1982; pp. $643-687$.

53. Lavoie, M.; Bradley, R.L. Short-term increases in relative nitrification rates due to trenching in forest floor and mineral soil horizons of different forest types. Plant Soil 2003, 252, 367-384. [CrossRef]

54. Tian, Y.; Toda, H. pH and substrate regulation of nitrogen and carbon dynamics in forest soils in a karst region of the upper Yangtze River basin, China. J. For. Res. 2013, 18, 228-237. [CrossRef]

55. Beck, T.; Joergensen, R.G.; Kandeler, E.; Makeschin, F.; Nuss, E.; Oberholzer, H.R.; Scheu, S. An inter-laboratory comparison of ten different ways of measuring soil microbial biomass C. Soil Biol. Biochem. 1997, 29, 1023-1032. [CrossRef]

56. Brookes, P.C.; Kragt, J.F.; Powlson, D.S.; Jenkinson, D.S. Chloroform fumigation and the release of soil nitrogen: The effects of fumigation time and temperature. Soil Biol. Biochem. 1985, 14, 831-835. [CrossRef]

57. Schroeder, J.; Jannoura, R.; Beuschel, R.; Pfeiffer, B.; Dyckmans, J.; Murugan, R.; Chavannavar, S.; Wachendorf, C.; Joergensen, R.G. Carbon use efficiency and microbial functional diversity in a temperate Luvisol and a tropical Nitisol after millet litter and $\mathrm{N}$ addition. Biol. Fertil. Soils 2020, 56, 1139-1150. [CrossRef]

58. Manzoni, S.; Taylor, P.; Richter, A.; Porporato, A.; Ågren, G.I. Environmental and stoichiometric controls on microbial carbon-use efficiency in soils. New Phytol. 2012, 196, 79-91. [CrossRef] [PubMed]

59. Trinsoutrot, I.; Recous, S.; Bentz, B.; Lineres, M.; Cheneby, D.; Nicolardot, B. Biochemical quality of crop residues and carbon and nitrogen mineralization kinetics under nonlimiting nitrogen conditions. Soil Sci. Soc. Am. J. 2000, 64, 918-926. [CrossRef] 
60. McFarland, J.W.; Ruess, R.W.; Kielland, K.; Pregiter, K.; Hendrick, R. Glycine mineralization in situ closely correlates with soil carbon availability across six North American forest ecosystems. Biogeochemistry 2010, 99, 175-191. [CrossRef]

61. Kirchmann, H.; Bergqvist, R. Carbon and nitrogen mineralization of white clover plants (Trifolium repens) of different age during aerobic incubation with soil. J. Soil Sci. Plant. Nutr. 1989, 152, 281-286. [CrossRef]

62. R Core Team. A Language and Environment for Statistical Computing; R Foundation for Statistical Computing: Vienna, Austria, 2015; Available online: https: / / www.r-project.org/ (accessed on 12 August 2020).

63. Huang, Y.; Zou, J.W.; Zheng, X.H.; Wang, Y.S.; Xu, X.K. Nitrous oxide emissions as influenced by amendment of plant residues with different C:N ratios. Soil Biol. Biochem. 2004, 36, 973-981. [CrossRef]

64. Silva, E.C.D.; Muraoka, T.; Franzini, V.I.; Sakadevan, K.; Buzetti, S.; Arf, O.; Bendassolli, J.A.; Soares, F.A.L. Use of nitrogen from fertilizer and cover crops by upland rice in an Oxisol under no-tillage in the Cerrado. Pesqui. Agropecu. Bras. 2016, 51, 728-737. [CrossRef]

65. Wagger, M.G. Time of desiccation effects on plant composition and subsequent nitrogen release from several winter annual cover crops. Agron. J. 1989, 81, 236-241. [CrossRef]

66. Carvalho, A.M.; de Souza, L.L.P.; de Guimarães Júnior, R.; Alves, P.C.A.C.; Vivaldi, L.J. Cover plants with potential use for crop-livestock integrated systems in the Cerrado region. Pesqui. Agropecu. Bras. 2011, 46, 1200-1205. [CrossRef]

67. Staaf, H.; Berg, B. Accumulation and release of plant nutrients in decomposing scots pine needle litter-Long-term decomposition in a scots pine forest. Can. J. Bot. 1982, 60, 1561-1568. [CrossRef]

68. Tian, G.; Brussaard, L.; Kang, B.T. An index for assessing the quality of plant residues and evaluating their effects on soil and crop in the (sub-) humid tropics. Appl. Soil Ecol. 1995, 2, 25-32. [CrossRef]

69. Kaschuk, G.; Alberton, O.; Hungria, M. Three decades of soil microbial biomass studies in Brazilian ecosystems: Lessons learned about soil quality and indications for improving sustainability. Soil Biol. Biochem. 2010, 42, 1-13. [CrossRef]

70. Gentsch, N.; Boy, J.; Batalla, J.D.K.; Heuermann, D.; von Wirén, N.; Schweneker, D.; Feuerstein, U.; Groß, J.; Bauer, B.; ReinholdHurek, B.; et al. Catch crop diversity increases rhizosphere carbon input and soil microbial biomass. Biol. Fertil. Soils 2020, 56, 943-957. [CrossRef]

71. Argyropoulos, D.; Menachem, S. Lignin. In Biopolymers from Renewable Resources; Kaplan, D.L., Ed.; Springer: New York, NY, USA, 1998; pp. 292-322.

72. Jensen, E.S. Mineralization-immobilization of nitrogen in soil amended with low C:N ratio plant residues with different particle sizes. Soil Biol. Biochem. 1994, 26, 519-521. [CrossRef]

73. Woli, K.P.; Pantoja, J.L.; Sawyer, J.E. Soil inorganic nitrogen with incubation of rye cover crop biomass. Commun. Soil Sci. Plant Anal. 2016, 47, 2558-2572. [CrossRef]

74. Quemada, M.; Carbrera, M.L. Carbon and nitrogen mineralized from leaves and stems of four cover crops. Soil Sci. Soc. Am. J. 1995, 59, 471-477. [CrossRef]

75. Marstorp, H.; Kirchmann, H. Carbon and nitrogen mineralization and crop uptake of nitrogen from six green manure legume decomposing in soil. Acta Agric. Scand. 1991, 41, 243-252. [CrossRef]

76. Abera, G.; Wolde-Meskel, E.; Bakken, L.R. Carbon and nitrogen mineralization dynamics in different soils of the tropics amended with legume residues and contrasting soil moisture contents. Biol. Fertil. Soils 2012, 48, 51-66. [CrossRef]

77. Recous, S.; Machet, J.M.; Mary, B. The partitioning of fertilizer-N between soil and crop: Comparison of ammonium and nitrate applications. Plant Soil 1992, 144, 101-111. [CrossRef] 